\title{
UPPER CHRONOLOGICAL BOUNDARY OF SARGATHA CULTURE
}

\author{
Svetlana V. Sharapova \\ Institute of History and Archaeology Urals Branch of RAS, Ekaterinburg, Russian Federation
}

\begin{abstract}
The article deals with the antiquity of Sargat culture of forest-steppe in the Trans-Urals and Western Siberia. The established concepts of chronological framework cover the interval from the $5^{\text {th }}$ century BC to $4^{\text {th }}-5^{\text {th }}$ centuries AD. Recent studies, both in the main territory and outside the Sargat area, provide evidences for clarifying the upper chronological boundary of the culture. The bright Late Sarmatian appearance of some Sargat burial complexes allows to consider Late Sarmatian finds of the Southern Urals as a reference; rich material has been accumulated on them, as well as detailed chronology.Late Sargathian monuments are found only in two regions Tobol and Ishim rivers basins. The proposed correction is based on archaeological material which is external data (relative chronology) towards radiocarbon analysis (absolute chronology). In the archaeological collections of Sargat burials there are no any artifacts, the beginning of the period of existence of which falls on the $3^{\text {rd }}$ century AD. There is no such evidence in the settlements either. Furthermore, judging by the available materials, the number of such complexes is small and the inventory is quite poor. The article gives a detailed analysis of burials from seven kurgan cemeteries located in Tobol and Ishim rivers basins, which might be attributed to the latest group marking the upper chronological boundary. In the second half of the $3^{\text {rd }}$ century $\mathrm{AD}$, the main features of the Sargat culture are fading and blurred, besides, it is absent in most of the forest-steppe territory to the east of the Urals. In conclusion the author suggests that if the assumptions are correct, the disappearance of the bright expressive complexes that defined the image of the Sargat social and cultural system, looks quite sharp. The Sargat monuments of the $4^{\text {th }}$ century $\mathrm{AD}$ and later are not found across vast forest-steppe territory.
\end{abstract}

Key words: Early Iron Age, Sargat culture, Trans-Ural and Western Siberia forest-steppe, burials, accompanying inventory, dating.

Citation. Sharapova S.V., 2020. Verhnyaya hronologicheskaya granitsa sargatskoy kul'tury [Upper Chronological Boundary of Sargatha Culture]. Nizhnevolzhskiy Arkheologicheskiy Vestnik [The Lower Volga Archaeological Bulletin], vol. 19, no. 2, pp. 218-246. DOI: https://doi.org/10.15688/nav.jvolsu.2020.2.12

УДК 902.6-903.2/903.53

Дата поступления статьи: 30.05.2020

ББК 63.4(2)

Дата принятия статьи: 24.11.2020

\section{ВЕРХНЯЯ ХРОНОЛОГИЧЕСКАЯ ГРАНИЦА САРГАТСКОЙ КУЛЬТУРЫ}

\section{Светлана Владимировна Шарапова}

Институт истории и археологии Уральского отделения РАН, г. Екатеринбург, Российская Федерация

\footnotetext{
Аннотация. В статье рассматриваются древности саргатской культуры лесостепного Зауралья и Западной Сибири. Устоявшиеся представления о хронологических рамках охватывают интервал V в. до н.э. - IV$\mathrm{V}$ вв. н.э. Исследования последних лет, как на основной территории, так и за пределами саргатского ареала, дают основания для уточнения верхней хронологической границы культуры. Яркий позднесарматский облик некоторых саргатских погребальных комплексов позволяет рассматривать позднесарматские находки Южते ного Приуралья референтными, по ним также накоплен богатый материал и детально проработана хронолопия. Поздние саргатские памятники есть только в двух районах - Притоболье и Приишимье. Предлагаемая корректировка базируется с учетом внешних по отношению к радиоуглеродному методу данных, то есть по археологическому материалу. В коллекциях саргатских могильников не известны предметы, начало периода бытования которых приходится на III в. н.э. Нет таких свидетельств и на поселениях. Судя по имеющимся 丞 материалам, количество таких комплексов невелико, инвентарь довольно беден. В статье анализируются (0) погребения из семи курганных могильников в Притоболье и Приишимье, которые могут быть отнесены к
} 
поздней группе, и маркирующие верхнюю хронологическую границу. Во второй половине III в. н.э. происходит угасание и размывание основных черт саргатской культуры, она отсутствует на большей части лесостепи к востоку от Урала. Если мои допущения верны, то исчезновение ярких выразительных комплексов, определявших облик саргатской социокультурной системы, выглядит довольно резко. На обширном лесостепном пространстве саргатские памятники IV в. н.э. и позже не известны.

Ключевые слова: ранний железный век, саргатская культура, лесостепь Зауралья и Западной Сибири, погребения, сопроводительный инвентарь, датировка.

Цитирование. Шарапова С. В., 2020. Верхняя хронологическая граница саргатской культуры // Нижневолжский археологический вестник. Т. 19, № 2. С. 218-246. DOI: https://doi.org/10.15688/nav.jvolsu.2020.2.12

В раннем железном веке в лесостепи Зауралья и Западной Сибири обитало население, чьи древности в археологической систематике именуются саргатской культурой (рис. 1). В результате исследований многих поколений археологов был очерчен ареал распространения памятников, дана характеристика материальной культуры и погребальной обрядности, систематизирован вещевой комплекс, предложены гипотезы о происхождении и основной вектор связей. Поселения и могильники концентрируются главным образом вдоль крупных рек - Тобол, Ишим, Иртыш, а также по средним течениям Исети и Оми. В географическом отношении это пространство соотносится с ландшафтными провинциями лесостепи, что определило археологическое различие районов, отразившееся в особенностях погребального обряда, орнаментации керамики и конструкций жилищ, а также в динамике культуры [Корякова, 1988; Матвеева, 1993б, 1994; Могильников, 1992а; Полосьмак, 1987].

Поселения саргатской культуры представлены неукрепленными поселками и городищами - мысовыми и береговыми с замкнутой линией обороны, с разным количеством площадок ${ }^{1}$. Возрастание площади поселков связывается с существованием центров торговли и ремесла [Берлина, 2010, с. 7]. Одной из отличительных черт домостроительства считается устойчивое сочетание одно- и двухкамерных построек с различной глубиной котлована (рис. 2). Многокамерные сооружения соединялись коридорами-тамбурами [Корякова, 1994a, с. 259-275, рис. 14, 15]. Жилища на посаде аналогичны тем, что реконструированы для укрепленной площадки [Корякова и др., 2009, с. 34-87]. Вопрос о наличии земледелия [Могильников, 1992a, с. 307] по-прежнему открыт, поскольку палинологические данные не выявили следов культурных злаковых расте- ний в слоях зауральских городищ [Косинцев и др., 2003, с. 131]. Население сочетало подвижное скотоводство с охотой и рыболовством [Корякова и др., 2009, с. 262-266]. Согласуется с этими фактами и состояние зубочелюстной системы у индивидов из погребений, для которых регулярным было потребление продуктов животноводства при минимуме пищи из злаков. Тем не менее частота гипоплазийных дефектов эмали, железодефицитных состояний позволили говорить о недостатке сбалансированного питания [Ражев, 2009, с. 356360]. Косвенным подтверждением служат способы раскола костей для добывания костного мозга и жира. Интенсивность их употребления тесно связана с недостаточным обеспечением пищей [Корякова и др., 2009, с. 266].

Погребальный обряд предполагал ингумацию с последующим возведением кургана или захоронение в уже имеющейся насыпи [Корякова, 1994б, с. 149-153; Матвеева, 1994, с. 134-141]. В целом в саргатской культуре преобладает ориентировка умерших головой в северный и северо-западный сектор. Отклонения от господствующих направлений связывают не только с локальными проявлениями обрядности [Корякова, 1988, с. 50, табл. 1], но и с круговым расположением периферийных захоронений, большинство из которых было совершено позднее центральных с соблюдением планировочной структуры подкурганной площадки [Булдашев и др., 1997, с. 67, 69-70; Корякова и др., 2009, с. 203]. Подавляющее количество погребений в курганах принадлежит взрослым людям. Тафокомплекс демонстрирует заметное преобладание мужских скелетов над женскими (соотношение полов $1: 1,75)$, а также недопредставленность останков стариков и детей [Ражев, 2009, с. 50-55]. Дисбаланс между количеством людей, похороненных в курганах и проживавших на посе- 
лениях, позволил предположить существование альтернативных форм захоронений для большей части саргатского социума [Ражев, Ковригин, 1999]. Данное заключение согласуется с упомянутой половозрастной спецификой курганной выборки. Представляется, что племенной нобилитет, связанный генеалогией со степняками («ираноязычные кочевые группы» [Корякова, 1988, с. 159; 19946, с. 114-115, 152], «кочевники степей Казахстана и Южного Урала» [Могильников, 1992a, с. 293, 301]), занимал доминирующее положение, определив особенности саргатской обрядовой практики, отличной от традиции местного населения [Ковригин и др., 2006; Корякова и др., 2010]. Позднее эта гипотеза получила дальнейшее развитие. Так, А.Н. Багашев в ходе краниологического изучения индивидов из саргатских могильников выявил компоненты, связанные с сакским и савромато-сарматским населением [Багашев, 2000, с. 188]. При этом значительное сходство разных географических и хронологических серий внутри саргатской курганной выборки позволило говорить о единстве их расового облика («сибирский лесостепной» криниокомплекс в составе группы восточных европеоидов) [Ражев, 2009, c. 236]. Немногочисленные пока результаты палеогенетических исследований выявили внешнее генетическое влияние как в составе генофонда мтДНК саргатского населения, так и в результате генотипирования Y-хромосомы, при сохранении вариантов, характерных для лесостепных групп Барабы, Прииртышья и Притоболья [Пилипенко и др., 2017; Шарапова и др., 2020]. Изучение погребальной обрядности позволило заключить, что ее проявления близки канонам, распространенным в кочевнической среде. Сопроводительный инвентарь, в котором заметную долю составляют предметы вооружения и конская сбруя, повторяет расхожие образцы [Корякова, 1988, с. 159; Могильников, 1972; 1992a, с. 302-303] и демонстрирует репрезентативные инсигнии, связанные с мужской субкультурой лесостепного и степного населения железного века Евразии [Шарапова, 2018]. Помимо обрядности и домостроительства характерные черты саргатской культуры включают лепную керамику. Во всех немногочисленных неграбленых погребениях (например, могильники Сидоров- ка и Исаковка I в Прииртышье) наряду с беспрецедентным по богатству инвентарем импортного происхождения всегда находились лепные саргатские сосуды. Без них эти погребения, без сомнения, могли быть определены как оставленные кочевниками.

Устоявшиеся представления о хронологических рамках саргатской культуры охватывают интервал V в. до н.э. - IV-V вв. н.э. [Корякова, 1994б, с. 129; Матвеева, 2000, с. 125-126; 2017; Могильников, 1992а, с. 296]. В ее развитии выделены этапы формирования или предсаргатский - VII-VI вв. до н.э.; подъема или саргатско-гороховский - VIII вв. до н.э.; стабилизации или собственно саргатский - II в. до н.э. - II-III в. н.э.; трансформации или распада, именуемый позднесаргатским, - IV-V вв. н.э. [Корякова, 1991, с. 3347; 1994б, с. 129]. Существующая схема была выстроена с учетом относительной хронологии. В ней доминирует осознание того, что могло быть раньше, а что позже. Увы, наши знания о том, как все это могло соотноситься с реальным временем, крайне ограничены. Оттого временные интервалы зачастую очень широки, поскольку отражают общую тенденцию с учетом результатов изучения синхронных культур. Среди исследователей нет единства в определении границ периодов, наиболее обсуждаемыми остаются ранние и поздние этапы. Большинство свидетельств активной жизнедеятельности саргатского населения приходится на IV в. до н.э. - I-II вв. н.э. Этот временной диапазон в целом совпадает с периодом подъема и стабилизации культуры, археологически он фиксируется лучше. Беднее представлены периоды распада и трансформации. К сожалению, саргатская проблематика вышла из раскопочного мейнстрима: в противоположность количественному накоплению источников наметилась тенденция изучения «вглубь» материалов, полученных прежде. Появившиеся на этом пути исследования дают основания для уточнения верхней хронологической границы саргатской культуры, в том числе в пределах основной территории распространения. Некоторые мнения решительного пересмотра верхней хронологической границы нелишены оснований.

Критический анализ поздних саргатских комплексов и их датировок предприня- 
ли А.П. Зыков и Н.В. Федорова при обращении к материалам севера Западной Сибири [Зыков, Федорова, 2001]. Обсуждая этническое окружение таежного населения, авторы провели хронологическое сопоставление с археологическими памятниками лесостепной зоны и допустили возможность сужения хронологических границ саргатской культуры. Прежде всего, поздние памятники саргатской культуры известны только в двух районах - в Притоболье и Приишимье, - да и те датируются концом II - началом III в. н.э. По их мнению, в Омском Прииртышье саргатская культура прекращает свое существование не позднее II в. н.э., поскольку на I-II вв. н.э. здесь приходится распространение памятников позднекулайского населения. В результате саргатские группы, обитавшие в лесостепном Прииртышье, теряют свою культурную самобытность [Зыков, Федорова, 2001, с. 20]. Следующий аргумент связан со спецификой контактов населения по обе стороны Уральских гор. В саргатских могильниках Ипкульский и Абатский 3 известен пьяноборский и кара-абызский импорт [Корякова, 1988, рис. 20,13,15; Матвеева, 1994, рис. 58,21; и т. д.]. Относительно недавно в Притоболье были получены материалы, в которых есть находки, происходящие с территории Прикамья, и это комплекс рубежа эр - бескурганное погребение Сопининского 1 могильника [Корякова и др., 2009, с. 230-232, рис. 9,12]. Однако вещей мазунинской культуры, которая сменяет караабызскую и пьяноборскую в III-IV вв. н.э./ $\mathrm{V}$ в. н.э., в саргатских памятниках нет. Памятники с классическим набором признаков культуры в лесостепи Притоболья позднее середины III в. н.э. неизвестны [Зыков, Федорова, 2001, с. 19-20].

Справедливые возражения против датировки II-IV вв. н.э. Абатского 3 могильника были высказаны А.А. Ковригиным [Ковригин, 2007]. Он обратил внимание, что в коллекции присутствуют явно архаичные для этого времени вещи - бронзовые наконечники стрел и костяные псалии. Немногочисленный ранний материал происходит из разрушенных погребений кургана 2 [Матвеева, 1994, с. 63-65, рис. $38,15,16,18,21]$. Напротив, типологически монолитный комплекс бронзовых зеркал определяет возраст погребений, где они были найдены (кург. 2, погр. 5 и 17, кург. 6, погр. 10) [Матвеева, 1994, рис. 36, 18, 40,16, 59,9], в пределах I в. до н.э. - I-II вв. н.э. Из всей коллекции только несколько предметов имеют дату II в. н.э. и моложе [Ковригин, 2007, с. 195197]. К ним отнесены железные удила с большими кольцами-псалиями (кург. 6, погр. 8), плоский наконечник ремня (кург. 1, погр. 5) [Матвеева, 1994, рис. 30,39, 54,11, 57,2]. С учетом датировки предметов вооружения и воинского снаряжения, саргатские погребения абатских курганов отнесены к хроноинтервалу IIIII вв. до н.э. - II-III вв. н.э., при этом инвентарь основной части могил соотносится с I в. н.э. [Ковригин, 2007, с. 198].

В.Е. Маслов пересмотрел датировку инвентаря из погр. 10 кург. 6 Абатского 3 могильника. Наряду с менее выразительными находками вещевой комплекс этого захоронения включал ханьский меч с бронзовым перекрестием, железный кинжал, бронзовое зеркало бактрийского типа, поясную пряжку с лаковым покрытием и гравировкой [Матвеева, 1994 , с. 93-96, рис. 58,8, 59]. Вопреки мнению Н.П. Матвеевой, верхняя дата этого погребения не может выходить за пределы I в. н.э. [Маслов, 2018, с. 34]. Как видно, разные авторы солидарны в оценке хронологической позиции поздних погребений могильника.

Систематизируя пестроту лесостепных образований эпохи железа, С.Г. Боталов отметил, что термин «археологическая культура» (АК) «сегодня является недостаточно широким и универсальным». В качестве альтернативы им был предложен историко-культурный горизонт (ИКГ) для изложения своего видения верхней даты саргатской культуры [Боталов, 2016, с. 468, 473]. Диссонанс вносит не столько сама возможность использования ИКГ, сколько понятийные расхождения. Так, в хрестоматийном определении Л.С. Клейна, горизонт представляет собой одномоментный хронологический срез, то есть «суть идеи горизонта - в синхронности его объектов» [Клейн, 2012, с. 293]. Однако у С.Г. Боталова для обоснования ИКГ привлекается типологически разнообразная зауральская лесостепная керамика. При этом столь характерная для эпохи морфологическая и орнаментальная непрерывность керамических комплексов декларируется, но не учитывается. Более того, 
методическое своеобразие и произвольное обращение с фактами вынуждают относиться к доводам автора с известной осторожностью. Исходя из принципа последовательной сменяемости культур, С.Г. Боталов заполнил лакуну в хронологической шкале лесостепных древностей. Позднесаргатская фаза доведена до рубежа III-IV вв. н.э., «когда также повсеместно начинает складываться бакальский ИКГ» [Боталов, 2016, с. 473]. С одной стороны, принято считать, что бакальские памятники оставлены группой населения, унаследовавшего часть саргатских традиций [Сальников, 1956, с. 211-214; Могильников, 1987, c. 179-183]. С другой - бакальские древности, нижняя граница которых отнесена к IV$\mathrm{V}$ вв. н.э., остаются слабо изученными, а их количество невелико [Рафикова, 2011]. В качестве одного из поселений, где фиксируется и формируется бакальский керамический комплекс, приводится Павлиново городище [Боталов, 2016, с. 473]. Пример спорный, поскольку раскопки памятника не выявили ни на посаде, ни на цитадели объектов с бакальскими сосудами. В ходе морфологического анализа керамической коллекции были определены только единичные бакальские фрагменты, происходящие с периферии посада, причем их нахождение в верхних руинированных слоях свидетельствует, что к середине I тыс. н.э. поселок прекратил свое функционирование. Основу коллекции разновременных объектов Павлинова городища составляет саргатская керамика [Корякова и др., 2009, с. 107-134]. Также неоднозначна датировка I-VI вв. н.э. Большого Бакальского городища, предложенная С.Г. Боталовым, для определения периода бытования саргатских и бакальских комплексов [Боталов и др., 2008] ${ }^{2}$. Судя по описанию и иллюстрациям керамического инвентаря в публикации, саргатских сосудов в коллекции памятника нет [Боталов и др., 2008, с. 16-27, рис. 4-14]. Вопрос о соотношении выявленных объектов с выделенными керамическими группами, понимании стратиграфии авторами работ на Большом Бакальском городище остается открытым.

Собрав представительную серию радиоуглеродных дат из памятников Притоболья, Приишимья и Барабы, Н.П. Матвеева вернулась к проблемам хронологии культуры [Мат- веева, 2017]. После обобщения комбинированных дат начало IV в. н.э. было определено периодом смены культуры раннего железного века средневековой в северной части лесостепи и подтаежной зоне. Сместив позднюю дату саргатской культуры к первой половине IV в. н.э., она в целом согласилась с теми исследователями, которые склонны к пересмотру верхней хронологической границы. Однако, по мнению Н.П. Матвеевой, в II-III вв. н.э. происходит лишь ослабление культуры, угасание растянулось на полвека - век [Матвеева, 2017, с. 15-16].

В этой связи уместно рассмотреть некоторые особенности радиоуглеродного датирования. Прежде всего необходимо иметь в виду не только проблему «искажающих эффектов», когда радиоуглеродные даты не совпадают с археологическими, даже многократно проверенными разными методами [ван дер Плихт и др., 2016; Марсадолов, 2016; и др.]. В ряде случаев сохранность археологического материала предопределяет случайность формирования наших выборок в целом и образца для датирования в частности. Для радиоуглеродного анализа саргатских древностей чаще всего используется органика кость или остатки древесины. Сейчас уже не отрицается, что для образцов кости человека необходима поправка на изотопное фракционирование [ван дер Плихт и др., 2016, с. 1618], что невозможно для образцов, по которым нет данных о соотношении изотопов углерода и азота, а также результатов датирования костей животных или растений из того же контекста. Последнее весьма справедливо практически ко всем датированным радиоуглеродным способом саргатским объектам.

В такой неоднозначной ситуации представляется возможной корректировка с учетом внешних по отношению к радиоуглеродному методу данных, то есть по археологическому материалу. Здесь стоит отметить, что методика датирования поздних саргатских памятников за последние десятилетия принципиально не изменилась. Чаще всего хронология погребений устанавливается по верхнему пределу бытования вещей, определяемому по аналогиям. Подобная практика неизбежно делает датировки завышенными. Ситуация сохранилась и после расширения 
корпуса источников и включения в него памятников, раскопанных относительно недавно. Исключение составляют некоторые типы стеклянных бус, имеющих широкий интервал бытования, а время и место их производства вызывают значительные расхождения (ср.: [Ковригин, 2007; Матвеева, 2017]). Вынужденно оперируя материалами по классификации северопричерноморских бус Е.М. Алексеевой [Алексеева, 1978] - единственным в своем роде фундаментальным трудом, - не стоит упускать из виду, что основная часть бус в саргатских могильниках происходит из других регионов. Как показало исследование Н.П. Довгалюк, многие образцы связаны своим происхождением с мастерскими в Египте, на Ближнем Востоке, возможно, в Китае и Индии [Довгалюк, 1995, с. 15]. А.А. Ковригин справедливо отметил, что развитие школ стеклоделия на разных территориях не обязательно должно совпадать [Ковригин, 2007, с. 197]. Н.П. Матвеева, оспаривая доводы оппонента, настаивает на позднем диапазоне бытования ряда бус из погребений Абатского 3 могильника, аналогии которым усматривает все же в Северном Причерноморье [Матвеева, 2017, с. 13].

Представляется, что за неимением убедительных датировок отдельных памятников, а также с учетом яркого позднесарматского облика некоторых саргатских погребальных комплексов, референтными могут быть позднесарматские находки Южного Приуралья, ограничивающие преимущественно нижнюю дату позднего этапа саргатской культуры. По ним в настоящее время не только накоплен богатый материал, но и детально проработана хронология [Малашев, Яблонский, 2008; Малашев, 2013]. Кроме того, сходство сарматских и саргатских древностей в типологическом контексте археологии железного века Евразии не отрицается. Анализ доступных источников по саргатской культуре выявил комплексы, относимые к погребениям поздней хронологической группы. Они известны в материалах семи могильников. Их небольшое количество позволяет рассмотреть все.

Самым северным в ареале саргатских древностей является Ипкульский могильник, расположенный в подтаежной зоне Нижнего Притоболья. Саргатские признаки есть в по- гребениях курганов 1-5, 13, 18, 20, 24, датированных авторами раскопок III-IV вв. н.э. [Корякова, 1988, с. 86; Чикунова, 2017, с. 106, 108, pис. 3-8, 13, $B, \Gamma, E$, табл. 1]. Имеющиеся в коллекции детали сбруйного набора и ременных гарнитур (бронзовые накладки со штифтом, бронзовые кольца, бронзовые пряжки с округлой или овальной рамкой), двухчастные наконечники-подвески с расширением округлой формы в нижней части изделия аналогичны позднесарматским образцам середины - второй половины III в. н.э. [Малашев, 2000, с. 209, 210]. В рамках этого же интервала могут рассматриваться серия деформированных черепов и сохранившиеся керамические традиции, устойчивость которых не исключает принадлежность этих объектов к поздней группе саргатских погребений. Другие хронологически поздние и/или инокультурные (карымские, кушнаренковские) признаки позволяют определить время функционирования могильника и несколько позднее - вплоть до IV в. н.э.

Самые южные некрополи, в которых есть захоронения, относимые к саргатским, расположены в степях Северного Казахстана. Погребения курганов 2 и 4 могильника Покровский, 5 и 6 могильника Явленка 1 на основании вещевого комплекса датированы второй половиной II - III в. н.э. [Боталов, Гуцалов, 2000, с. 58-63, 142, рис. 18,I,III]. Принадлежность к кругу саргатских древностей устанавливается по лепным сосудам с уплощенным дном и резным орнаментом в виде фестонов и костяным наконечникам стрел, стандартным для саргатских колчанов.

Вслед за А.А. Ковригиным допускаю, что в Абатском 3 могильнике к группе поздних саргатских захоронений можно отнести погребение 5 кургана 1 и погребение 8 кургана 6 . Напомню, в инвентаре этих комплексов присутствуют бронзовый наконечник ремня и железные двусоставные удила с большими кольцами (ср.: [Ковригин, 2007, с. 197; Матвеева, 1994, с. 99-100; Малашев, Яблонский, 2008 , с. 50, 56]). Вопросы датировки этих и других элементов воинской субкультуры будут рассмотрены ниже на примере притобольских материалов.

В Притоболье саргатские комплексы, маркирующие верхнюю хронологическую границу культуры, представлены впускными по- 
гребениями поздней группы в могильниках Савиновский (кург. 5, погр. 3), Тютринский (кург. 3, погр. 3 и 4; кург. 10, погр. 3) [Матвеева, 1993б, с. 155], Гаевский 1 (кург. 3, погр. 4, кург. 6, погр. 1 и 2, кург. 7, погр. 3) [Булдашев и др., 1997, с. 65, 67-68].

Выделяя две хронологические группы в Савиновском могильнике, Н.П. Матвеева, тем не менее, исключила вероятность позднесаргатского компонента, определив верхнюю датировку некрополя I-II вв. н.э. [Матвеева, 19936 , с. $155 ; 2000$, c. $124-126 ; 2017$, c. 15]. Однако разрушенное погребение 3 кургана 5 содержало весьма выразительный инвентарь, позволивший первоначально установить дату II-III вв. н.э. [Матвеев, Матвеева, 1991, с. 44]. Вещевой комплекс включал бронзовые парные наконечники-подвески [Матвеев, Матвеева, 1991 , с. 21 , рис. $16,2,3]$, которые в рамках сарматской хронологии рассматриваются в качестве хронологического репера. Плоские бронзовые пластины с одним округлым краем и прорезью на другом конце типологически неоднородны, различается и их функциональное назначение - это и элементы крепления поясной гарнитуры, и обувные наконечники. Они известны в погребениях первых веков н.э. в пределах ареала распространения саргатской культуры [Булдашев и др., 1997, с. 45, рис. $28,2,3$; Матвеева, 1994 , с. 53 , рис. 30,39$]$, а также степного пояса [Гущина, Засецкая, 1994, c. 116, табл. 17,161; Малашев, Яблонский, 2008 , с. 56, рис. 203,11-18; Максименко, Безуглов, 1987 , с. 185 , рис. $2,18,19$; Могильников, 19926, с. 456 , табл. 106,8$]$. Считается, что пропорции части наконечников-подвесок не были постоянными на протяжении всего периода их бытования, потому форма этих предметов весьма показательна для хронологической оценки. Относительно длинные наконечники без расширения в нижней части характерны в основном для середины III в. н.э. [Малашев, 2000, с. 209, 210]. С другой стороны, признается, что наконечники-подвески становятся распространенной принадлежностью ременных наборов евразийских кочевников с I в. н.э. В таком виде доживают до середины II в. н.э., когда происходит их модификация и начинается повсеместное использование металлического зажима для крепления с ремнем [Малашев, 2000, с. 209, 210;
Малашев, Яблонский, 2008, с. 57]. Между тем в саргатских погребениях (Савиновский, кург. 5, погр. 3; Абатский 3, кург. 1, погр. 5; Гаевский 1, кург. 7, погр. 3) наконечники ремней именно таких форм - удлиненные и без зажимов для ремней [Матвеева, 1993б, с. 24, рис. $10,13,14 ; 1994$, с. 53 , рис. 30,39 ; Булдашев и др., 1997, с. 45, рис. 28,3,4]. Другим предметом для уточнения датировки могла бы быть бронзовая пряжка с подвижным язычком. Однако точные аналогии данному экземпляру не известны. Можно лишь добавить, что стилистически близкие образцы рамчатых пряжек лировидной формы изредка встречаются в сарматских памятниках I в. до н.э. - II в. н.э. Волго-Донского междуречья [Мошкова, 1989a, с. 189, табл. 8237], хуннских I в. н.э. Монголии [Кызласов, 1955 , с. 218 , рис. 20,4 ; Миняев, Елихина, 2010, c. 177], среди «южноалтайских репликатов» II-IV вв. н.э. [Сорокин, 1977, с. 63, рис. 8]. Допуская возможную позднюю датировку изделия, погребение 3 кургана 5 Савиновского могильника может быть отнесено к середине II в. н.э. - второй половине III в. н.э., вероятно, без финала столетия.

Погребения Тютринского могильника были отнесены Н.П. Матвеевой к позднему этапу по типологии инвентаря и дополнены радиоуглеродным анализом [Матвеева, 1993б, с. 156 , рис. $30,18-31,33-40,32,14 ; 2017]$. Интерес для оценки хронологии могут представлять круглая рамчатая железная пряжка с подвижным язычком без щитка (кург. 10, погр. 4), бронзовое зеркало с валиком по краю и ручкой-штырем (кург. 10, погр. 3), а также фаянсовый амулет в виде фигурки Гарпократа (кург. 3, погр. 3) из разрушенных захоронений. Аналогии этим предметам за пределами саргатской территории датируются II-III вв. н.э. [Малашев, 2016, с. 50-53, 145, рис. 78,1; Хазанов, 1963, с. 65; Бурков, 2014, с. 183].

К числу памятников, которые можно считать опорными для понимания исторических процессов финала раннего железного века, относится Гаевский 1 могильник в Притоболье [Булдашев и др., 1997]. Публикация результатов палеогенетического анализа двух индивидов из непотревоженных погребений 1 и 2 кургана 6 (рис. 3,4$)$ не только позволила скорректировать прежнюю датировку захоро- 
нений, но и изменить устоявшиеся на сегодняшний день представления о верхней хронологической границе культуры в целом [Шарапова и др., 2020]. Остановлюсь подробнее на этом вопросе, начав с характеристики инвентаря этих комплексов.

Предметы вооружения и конской упряжи из погребения 1 имеют аналогии как в материалах собственно саргатской культуры, так и в памятниках западного ареала степного пояса Евразии (рис. 5). Установленный по инвентарю временной диапазон I-III вв. н.э. [Булдашев и др., 1997, с. 67] может быть уверенно использован при выборе участка интервала, полученного по результатам радиоуглеродного датирования, осуществленного позднее. Калиброванные значения ${ }^{3}$ двух дат, полученных по костям человека, составляют 592-196BCcal $(1 \sigma), 846 \mathrm{BC}-70 \mathrm{ADcal}(2 \sigma)$ $(2320 \pm 200$, Ле-5515) и 56AD-258ADcal $(1 \sigma)$, 50BC-401ADcal $(2 \sigma)(1850 \pm 100$, Лe-6104). Образцы предсказуемо не проходят $\chi^{2}$-тест на согласование, следовательно, одна из дат ошибочна. Причину ошибки по прошествии времени и недостаточности данных об изотопном составе образца установить невозможно. Скоpeе всего, большое квадратическое отклонение - результат малого количества выделенного коллагена и, как следствие, большого разброса результатов измерений. Археологическим ожиданиям соответствует более поздняя дата, уточнение по которой в рамках полученного интервала статистически невозможно, но внешние по отношению к радиоуглеродному методу данные - период бытования инвентаря - не противоречат абсолютным значениям.

На этом пути наиболее показательными являются железный кинжал без навершия и перекрестия (рис. 5,14 ) и удила с глухими кольцами и дополнительной рамкой для ремня поводьев (рис. 5,20 ) и в меньшей степени - круглорамчатая пряжка (рис. 5,5). Изготовленная из железа, из-за плохой сохранности она плохо атрибутируема. Прогиб язычка не определяется, однако он подвижный, его длина доходит до середины сечения. Из-за коррозии также довольно трудно определить наличие/ отсутствие щитка. Всевозможные округлые пряжки с подвижным язычком появляются с рубежа эр [Мошкова, 1989a, с. 189]. В сар- гатских погребениях они сопровождают вещи II в. до н.э. - II в. н.э. [Корякова, 1988, с. 76]. Сравнительно короткие язычки, наряду с другими признаками - округлая рамка, прогиб язычка в средней части, без щитка или с металлическим щитком - известны среди образцов второй половины II - первой половины III в. н.э. и позднее [Малашев, 2000, с. 209; Малашев, Яблонский, 2008, с. 51].

Мечи и кинжалы без металлического навершия и перекрестия являются характерными типами позднесарматских комплексов [Малашев, 2013, с. 12], массово встречаются на протяжении II-IV вв. н.э. [Хазанов, 1971, c. 20]. Для подобных клинков на территории Западной Сибири период бытования был установлен в переделах I-IV вв. н.э. [Корякова, 1988, c. 67].

Распространение больших колец железных удил приходится на рубеж эр [Граков, 1977, c. 67]. В саргатских погребениях они встречаются совместно с предметами I в. до н.э. IV в. н.э. [Корякова, 1988, с. 70]. Экземпляр удил из Гаевского 1 могильника отличает небольшой диаметр колец (всего 5-6 см), наличие специальной рамки для крепления ремней, что сближает его с уздечными наборами позднесарматского времени Южного Приуралья [Малашев, Яблонский, 2008, с. 50].

Присутствие костяных наконечников стрел в колчанном наборе и именно в таком сочетании также свидетельствует в пользу поздней датировки комплекса (рис. 5,6,13).

Костяные концевые накладки сложносоставного лука тоже не противоречат предложенной временной оценке, несмотря на то что их появление в саргатских погребениях относят ко II в. до н.э. [Корякова, 1988, с. 65] или даже к III в. до н.э. [Могильников 1992а, c. 302]. В Гаевском 1 могильнике оба комплекта происходят из кургана 6 (рис. 5,15-18, 6,22-25).

В пользу поздней даты рассматриваемого захоронения свидетельствуют и выявленные особенности погребального сооружения. Разного рода заплечики и уступы при оформлении могил использовались в саргатской погребальной практике довольно часто. Отличительной чертой являются довольно низкие асимметричные заплечики и узкая (по меркам саргатской культуры) погребальная каме- 
$\mathrm{pa}^{4}$. Близкие по основным параметрам могилы известны в лесостепи Притоболья и Приишимья в поздних погребениях, датируемых первыми веками н.э. [Мошкова, Генинг, 1972, с. 87-118; Матвеева, 19936, с. 155; 1994, с. 119; Ковригин и др., 2006, с. 192-193, 196-197]. В степи узкие могильные ямы, наряду с другими известными особенностями погребального обряда и обычаем деформации, относятся к основным диагностическим признакам позднесарматской культуры [Смирнов, Попов, 1972 , с. 24; Малашев, Мошкова, 2010, с. 38; Малашев, 2013, с. 8]. В головном краю погребения 1 имеется нишеобразное расширение для установки заупокойных даров, что также выходит за рамки саргатских погребальных канонов. Несмотря на то что речь не идет о полном соответствии формам погребальных сооружений, тем не менее, наличие ниш в могилах находит параллели в памятниках джетыасарской культуры. Подкурганные сырцовые склепы населения Юго-Восточного Приаралья характеризуются массовым использованием ниш: примерно половина сооружений приходится на ямы с нишами, но есть и ямы без них [Левина, 1996, с. 92, 107].

С учетом изложенного выше, можно допустить, что погребение 1 кургана 6 Гаевского 1 могильника было совершено не ранее второй половины II - первой половины III в. н.э. Прочий инвентарь (нож, полусферические стержневые бляшки, бронзовый гвоздик) (рис. 5, 1-3,9) не противоречит предложенной дате.

По инвентарю (рис. 6, 7) датировка погребения 2 определена в рамках II-III вв. н.э. [Булдашев и др., 1997, с. 67]. Радиоуглеродная дата, полученная по костям человека, имеет калиброванные значения 2 BC cal-60 AD cal $(1 \sigma), 45$ BC cal-77 AD cal $(2 \sigma)$

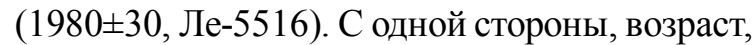
установленный инструментальным методом, соответствует датировке по аналогиям; с другой - полученный интервал несколько удревняет комплекс. Нередко самое простое - отбраковка не укладывающегося в ожидаемую концепцию радиоуглеродного определения, но и здесь возможна корректировка по археологическому материалу.

Во-первых, наблюдается тождественность основных категорий инвентаря погре- бений 1 и 2 кургана 6 Гаевского 1 могильника. Почти все находки известны как в памятниках лесостепного Зауралья и Западной Сибири, так и за пределами саргатской ойкумены. Во-вторых, разнообразный сопроводительный инвентарь все же содержит предметы, хоть и имеющие широкий диапазон бытования, но их присутствие в данном комплексе позволяют определить временной интервал совместного нахождения. Помимо упомянутых удил с кольчатыми псалиями и дополнительными металлическими зажимами для ремня поводьев (рис. 6,21) и рамчатых пряжек, сюда могут быть отнесены железный меч без металлического навершия и перекрестия, а также железные наконечники срезни из колчанного набора. В-третьих, умерший мужчина имел прижизненную деформацию черепа, которую вкупе с узкой прямоугольной ямой относят к ведущим признакам позднесарматского культурного комплекса, что уже упоминалось.

В Западной Сибири находки железных кольчатых удил с дополнительными зажимами известны от лесостепи до северной тайги вплоть до XVIII в. Это самый распространенный тип удил, оканчивающихся кольцами [Зыков и др., 2017, с. 204]. Железные кольчатые удила с дополнительными зажимами или рамками представлены различными вариантами в сарматской упряжи [Мошкова, 1989б, с. 386, табл. $81,42,43,49]$. В частности, в могильнике Покровка 10 в позднесарматских погребениях находились удила с разным диаметром колец (3,7-5,2 см и 9 см). Причем зажимы, по одному на кольце, отмечены как раз на крупных псалиях в погребении воина в кургане 43 [Малашев, Яблонский, 2008, с. 18]. Использование крупных колец (от 9 см диаметром) отличает узду, известную в памятниках лесостепной и лесной зоны Заволжья и Приуралья, но это не исключает существования наравне с ними удил с кольцами меньших размеров к востоку от Волги с III в. н.э. и позднее [Малашев, Яблонский, 2008, с. 50]. В целом в рассматриваемых гаевских экземплярах обращает на себя внимание конструкция удил с кольчатым трензелем, а именно крепление зажима или прямоугольной рамчатой петли не к кольцу, а к окончанию грызл. В синхронных памятниках европейской части сте- 
пи и прилегающих территорий (Северный Кавказ, Крым, лесостепная и лесная зоны ВолгоУралья) конструкция удил с кольчатым трензелем выглядит иначе: зажимы, относящиеся к ремням оголовья и повода, крепятся непосредственно к кольцу ${ }^{5}$. Исключением являются только удила иного типа - с колесовидными псалиями серии 1 по И.Р. Ахмедову, где два разновеликих металлических зажима крепятся к окончаниям грызл [Akhmedov, 2007, p. 68, pl. 56.8]. Скорее всего, на данных образцах саргатских удил металлические зажимы или петли служили для крепления ремней оголовья, а ремень повода соединялся непосредственно с кольцами. Учитывая такую специфику конструкции удил с кольчатым трензелем, их можно было бы считать самостоятельным вариантом описываемого типа удил, диагностирующим локальную традицию культуры. Однако в коллекциях других саргатских памятников подобные образцы не описаны и мне не известны.

Пряжки железные, безъязычковые или с подвижным язычком, по форме рамки представлены округлым, овальным или прямоугольным экземплярами (рис. 6-13,17,18). Преимущественно все относятся к поясной гарнитуре. Маленькая овальная с подвижным язычком, возможно, относилась к портупее. Все образцы известны в позднесарматских погребениях и не выходят за пределы III в. н.э. [Малашев, 2000, с. 221].

Бронзовые обоймы (рис. 6,7-12), изготовленные из пластины, относятся к деталям узды и нагаек. Широко встречаются в позднесарматских памятниках от Нижнего Подонья до Южного Приуралья [Мошкова, 1989б, c. 198; Малашев, Яблонский, 2008, с. 51; и др.]. В саргатских могильниках они есть в Приишимье, маркируя комплексы I-III вв. н.э. [Матвеева, 1994, с. 44-45].

Железный меч без металлического навершия и перекрестия (рис. 7,28) относится к характерному типу позднесарматского клинкового оружия [Хазанов, 1971, с. 20]. Близкий по морфологии экземпляр представлен в коллекции позднесарматского могильника Покровка 10 [Малашев, Яблонский, 2008, с. 59, 286]. На саргатской территории бытование подобных образцов приходится на I-IV вв. н.э. [Корякова, 1988, с. 67]. Судя по публикации, в могильнике Абатский 1 в саргатских могилах (кург. 3, погр. 4 и 11) находились аналогичные плохо сохранившиеся клинки. Комплексы датированы автором в пределах I-III вв. н.э. [Матвеева, 1994, с. 17-20, 22-25]. Гаевский меч обоюдоострый; истлевший кожаный ремень, обмотанный вокруг пяты клинка, выполнял функцию перекрестья; кожаная накладка была частью портупейной конструкции [Булдашев и др., 1997, с. 53].

Вытянутые пропорции костяных наконечников (рис. 7,8-11,16-18,23-27) аналогичны тем, что были в колчане из погребения 1. Присутствие в колчанном наборе закрытого комплекса железных наконечников срезней - с раздвоенным (вильчатый/двурогий) и долотовидным пером (рис. 7,6,7) - привносит определенную остроту обсуждению вопросов датировки. Прежде всего, в опубликованных материалах саргатской культуры подобные экземпляры не известны. Такие формы получают распространение не ранее середины I тыс. и происходят с территорий к северу, востоку и югу от ареала саргатских древностей [Булдашев и др., 1997, с. 49]. Аналогичными экземплярами, укладывающимися в хронологические рамки саргатской культуры, являются железные срезни, известные по сборам с кулайского городища Няксимволь и представленные в фондах Свердловского областного краеведческого музея ${ }^{6}$. Тот факт, что железные срезни находились в одном наборе с железными черешковыми трехлопастными (рис. 7,1-5) и костяными (рис. 7,8-27) наконечниками, не противоречит, а, скорее, подкрепляет предложенную датировку.

В анализируемых погребениях из кургана 6 могильника Гаевский 1 присутствуют признаки позднесарматской культуры, что позволяет их синхронизировать с позднесарматскими древностями второй половины II - III в. н.э. ${ }^{7}$ Принадлежность этих объектов к саргатской культуре и ее позднему этапу очевидна, равно как и рассмотренных выше немногочисленных захоронений в Савиновском и Тютринском могильниках в Притоболье и Абатском 3 могильнике в Приишимье. Археологически синхронные им погребения некрополей Ипкульский, Покровский и Явленка 1, расположенных на северной и южной границах саргатского ареала, демонстрируют лишь диспер- 
сное существование осколков саргатской культуры в Тоболо-Иртышском междуречье.

В этой связи интересно рассмотреть временной рубеж бытования саргатских стереотипов на поселениях, среди которых по степени изученности выделяются Павлиново и Коловское городища в Притоболье [Корякова и др., 2009; Матвеева и др., 2005]. Что касается материалов Рафайловского городища, которое Н.П. Матвеева включила в число опорных в хронологии саргатской культуры [Матвеева, 2017, табл.], остается сожалеть об отсутствии развернутой публикации этого интересного памятника эпохи железа лесостепного Зауралья. Материалы многолетних раскопок опубликованы только в сжатой форме, а время существования поселка на основании коллекции находок было отнесено к V-III вв. до н.э. [Матвеева, 1993а, c. 161]. Позже, с учетом данных радиоуглеродного анализа, верхняя дата была определена в диапазоне III-IV вв. н.э. [Матвеева, 2017 , с. 15]. Судя по керамическому инвентарю поселения, типологически весьма разнородному и разновременному, в коллекции присутствует значительная доля сосудов прыговского типа с характерной гребенчато-шнуровой орнаментацией [Матвеева, 1993a, с. 158, рис. 7,1,6,15-17]. К большому сожалению, в публикации отсутствует столь необходимый анализ соотношения керамики разных типов и выявленных объектов. Остается только догадываться, из каких сооружений происходят сосуды и каково их стратиграфическое соотношение с комплексом саргатской посуды. За неимением убедительных дат для прыговской керамики, можно обратиться к материалам раскопок Прыговского городища, где получены надежно стратифицированные данные соотношения зауральских типов керамики и объектов городища [Daire et al., 2002, p. 207-241]. Нижняя дата полученных прыговских материалов может быть смещена к отрезку времени не ранее II в. до н.э. рубежу эр [Шарапова, 2000, с. 24], то есть на каком-то этапе они синхронны саргатским ${ }^{8}$. Без анализа керамической коллекции Рафайловского городища и ее соотношения с обнаруженными там объектами сугубо саргатская принадлежность этого памятника исключается.
Время окончательного запустения крепости Павлинова городища, судя по датировкам построек внутри нее, отнесено ко второй половине I в. до н.э. - рубежу эр. После этого жизнь продолжалась только на посаде в I в. н.э. с заходом во II в. н.э. В пределах раскопанной части поселка сооружений, достоверно относящихся к верхней дате (II в. н.э.), не обнаружено, как нет и следов обитания позднее [Корякова и др., 2009, с. 169]. Приводимые Н.П. Матвеевой датировки объектов Коловского городища также согласуются с этими сведениями. Даты, относящиеся к основанию оборонительной стены, валу первой и третьей площадок цитадели, указывают на прекращение существования поселка во II в. н.э. [Матвеева и др., 2005, с. 58, 91; 2008, с. 152-153; Матвеева, 2017, с. 15].

Рассмотренные материалы подтверждают раннее наблюдение об отсутствии в саргатских могильниках вещей, начало периода бытования которых приходится на III в. н.э. [Зыков, Федорова, 2001, с. 19]. Нет таких свидетельств и на поселениях [Daire et al., 2002; Корякова и др., 2009; Матвеева и др., 2005; 2008]. Очевидно, что на рубеже II-III вв. н.э., на который приходится финальная фаза стабилизации саргатской культуры, по истечении короткого промежутка времени произошло исчезновение этого мощного социополитического организма. Весьма вероятно, вторая половина III в. н.э. знаменует постсаргатское время на обширном лесостепном пространстве. На макроуровне еще сохраняется присутствие не столь выразительного как прежде саргатского компонента по периферии общности - на подтаежных (Ипкульский могильник) и степных (могильники Покровский и Явленка 1) территориях. Так, часть саргатских групп, продвинувшаяся на север лесостепи, сохраняла свои традиции дольше, что отразилось в материалах поселений, датированных серединой I тыс. н.э. [Корякова и др., 1988]. В целом можно говорить, что саргатские традиции нашли выражение в курганном обряде и керамике населения, осевшего по обе стороны Урала. Этот процесс способствовал новому очагу культурогенеза, охватившего к VI в. н.э. широкую территорию северной лесостепи [Зыков, 2012, с. 47-50; Матвеева, Зеленков, 2018, с. 75]. 
Выше упоминалось, что саргатская погребальная атрибутика II-III вв. н.э. в значительной степени имеет выраженный позднесарматский облик. Реконструкции характера взаимоотношений лесостепного и степного населения на основании археологических данных имеют гипотетический характер, однако сам факт не оспаривается исследователями обеих культур. Допускается, что «часть населения саргатской культуры могла быть вовлечена в состав мигрантов и приняла участие в оформлении некоторых сторон позднесарматской культуры», так же как и факт совпадения финала существования степной и лесостепной культур [Малашев, Мошкова, 2010, c. 49; Малашев, 2013, с. 22]. Современные исследования позднесарматских памятников южноуральских степей не позволяют говорить о распространении их в регионе позже конца III в. н.э. [Малашев, 2009; 2013]. Несмотря на большие допущения, обусловленные искаженным характером археологической выборки по сравнению с реальной ситуацией, обращает на себя внимание связанность процессов в лесостепи и степи. В лесостепном ареале отмечается незначительное количество памятников позднего этапа саргатской культуры. Для степных территорий зафиксирован отток позднесарматского населения из Южного Приуралья [Малашев, 2009, с. 49-50; 2013, с. 6]. Различные по своей причинности факторы привели к фрагментарности саргатского компонента как на основной территории, так и на периферии лесостепи, а также к сокращению ареала позднесарматской культуры. Относительно недавно факт последнего стали объяснять неблагоприятными для кочевого хозяйства процессами гумидизации, охватившими Южное Приуралье со второй половины III в. н.э. и в финале столетия достигшими волго-донских степей [Кривошеев, Борисов, 2019]. Примечательно, что на смену точки зрения о хуннском нашествии в качестве основной причины распада саргатской культуры [Могильников, 1992a, с. 311] появилось мнение о комплексе причин. В их число включаются дестабилизация в восточных районах Евразии и ухудшение природно-климатических условий в лесостепи [Булдашев и др., 1997, с. 154; Матвеева и др., 2005, с. 11-12, 209]. Свидетельства локального увлажнения были получены в ходе анализа споро-пыльцевого спектра образцов, взятых из погребенной почвы курганов Притоболья. По мнению почвоведов, присутствие пыльцы лабазника и спор сфагновых мхов в выделенном спектре маркирует увлажненность [Корякова и др., 2009, с. 245]. Однако эти данные нуждаются в сравнении с результатами целенаправленных исследований природной среды в пределах всего ареала саргатской культуры, что пока не проводилось. Тем не менее анализ притобольских материалов позволил Н.П. Матвеевой заключить, что в раннем железном веке природные условия способствовали вовлечению лесостепных групп в историю населения прилегающих степей [Матвеева и др., 2005, с. 9-11].

По-видимому, саргатская культура в качестве целостного культурного явления с начала III в. н.э. отсутствует на бо́льшей части лесостепи к востоку от Урала. Судя по известным материалам, количество таких комплексов невелико, инвентарь довольно беден. Общепринято (и это подтверждается археологическим материалом), что Зауральская лесостепь была занята немногочисленной группой лесного населения, оставившего памятники с кашинско-прыговской (гребенчато-шнуровой) керамикой; лесостепи Омского Прииртышья и северной части Барабы заселили выходцы из северных таежных районов с керамикой позднекулайского облика. C IV в. н.э. отдельные элементы культуры, фиксируемые в подкурганном обряде погребения и схожих керамических традициях, сохраняются в подтаежной и степной зонах Тоболо-Ишимья (бакальские, карымские группы), либо интегрируются в местной среде к западу от Уральских гор (неволинские, кушнаренковские группы). В принципе, высказанное суждение не контрастирует с позицией Л.Н. Коряковой, Н.П. Матвеевой, В.А. Могильникова - расцвет саргатской культуры пришелся на II в. до н.э. - II в. н.э. Отличия касаются оценочно-содержательной коннотации следующего этапа, который вместо привычного названия позднесаргатским следовало бы именовать постсаргатским. Во второй половине III в. н.э. происходит угасание и размывание основных черт саргатской культуры. Если мои допущения верны, то исчезновение ярких выразительных комплексов, определявших облик саргатской социокультур- 
ной системы, выглядит довольно резко. На обширном лесостепном пространстве саргатские памятники IV в. н.э. и позже мне не известны.

Таким образом, синхронность заключительного этапа саргатской культуры и позднесарматской культуры Южного Приуралья второй половины II - III в. н.э. не исключается. Однако материалов, позволяющих раскрыть механизм взаимодействия (которое не отрицается) лесостепных и степных групп, пока явно недостаточно. Время, предшествующее финалу III в. н.э. и до сложения бакальской культуры в лесостепи, можно рассматривать «темными веками». Все вышесказанное допускает корректировку верхней хронологической границы саргатской культуры до середины - второй половины III в. н.э.

\section{ПРИМЕЧАНИЯ}

1 Площадки - на поселениях взаимосвязанные части замкнутого жилого пространства, ограниченного линией или линиями валов и рвов или естественными барьерами [Стоянов, 1970, с. 239].

${ }^{2}$ В публикации отсутствует хроностратиграфический анализ бакальской керамики (группа 1, к которой отнесено 86 \% сосудов, на самом деле включает и другие типологические группы зауральской керамики - гороховскую, кашинскую, прыговскую [Боталов и др., 2008, рис. 4,2, 6,11, 8,4,15,18,19]). Однако планиграфическое распределение дано всего для шести бакальских сосудов, которые залегали не на полу, а в верхнем заполнении хозяйственного сооружения, на что С.Г. Боталов и соавторы не обратили внимание [Боталов и др., 2008, с. 19, 33]. Данное обстоятельство вызывает сомнение в выделении бакальского горизонта и его синхронизации с кушнаренковско-караякуповской керамикой, как минимум, в пределах раскопанной части городища. Основной комплекс, включая бакальскую керамику, вопреки утверждениям С.Г. Боталова [Боталов и др., 2008, с. 34], находился в слое в переотложенном состоянии.

3 Калибровка проведена в программе OxCal 4.3.2 [Bronk Ramsey, 2017], калибровочная кривая IntCal13 [Reimer et al., 2013].

4 Удлиненно-прямоугольные могилы варьируют по своим размерам; узкими считаются те, у которых ширина камеры составляет около $1 / 2$ их длины [Мошкова, 1989a, с. 178]. Среди погребальных памятников Зауралья Гаевский 1 могильник выделяется статистическими значениями абсолютных размеров ям поздней хронологической группы при небольших показателях среднего квадратического отклонения. В них почти половину пространства ямы занимал лук, помещавшийся слева от умершего [Булдашев и др., 1997, с. 132-136, табл. 14].

5 Пользуясь случаем, выражаю благодарность В.Ю. Малашевуза помощь в детализации конструктивных особенностей удил.

${ }^{6}$ Памятники кулайской культуры занимают таежную зону Северо-Западной Сибири, обсуждение их датировки имеет дискуссионный характер, однако «пульсация» ареала схожих по облику культур приходится на II-І вв. до н.э. - первую половину IV в. н.э. [Зыков, 2012, с. 44-45].

7 В раскопанных гаевских курганах им одновременны два сильно разграбленных захоронения кург. 3, погр. 4 и кург. 7, погр. 3 [Булдашев и др., 1997 , c. 65,68$]$.

8 Для Прыговского городища по костям собаки из объекта с прыговской керамикой получена радиоуглеродная дата - $16 \mathrm{AD}$ cal-116 AD cal $(1 \sigma)$,

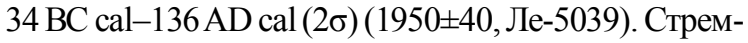
ление отнести памятник к саргатской культуре [Матвеева, 2000, с. 31, рис. 6; Могильников, 1992а, карта 20] едва ли оправданно. Среди раскопанных объектов саргатских сооружений нет [Ковригин, Шарапова, 1998, с. 51]. 


\section{ИЛЛЮСТРАЦИИ}

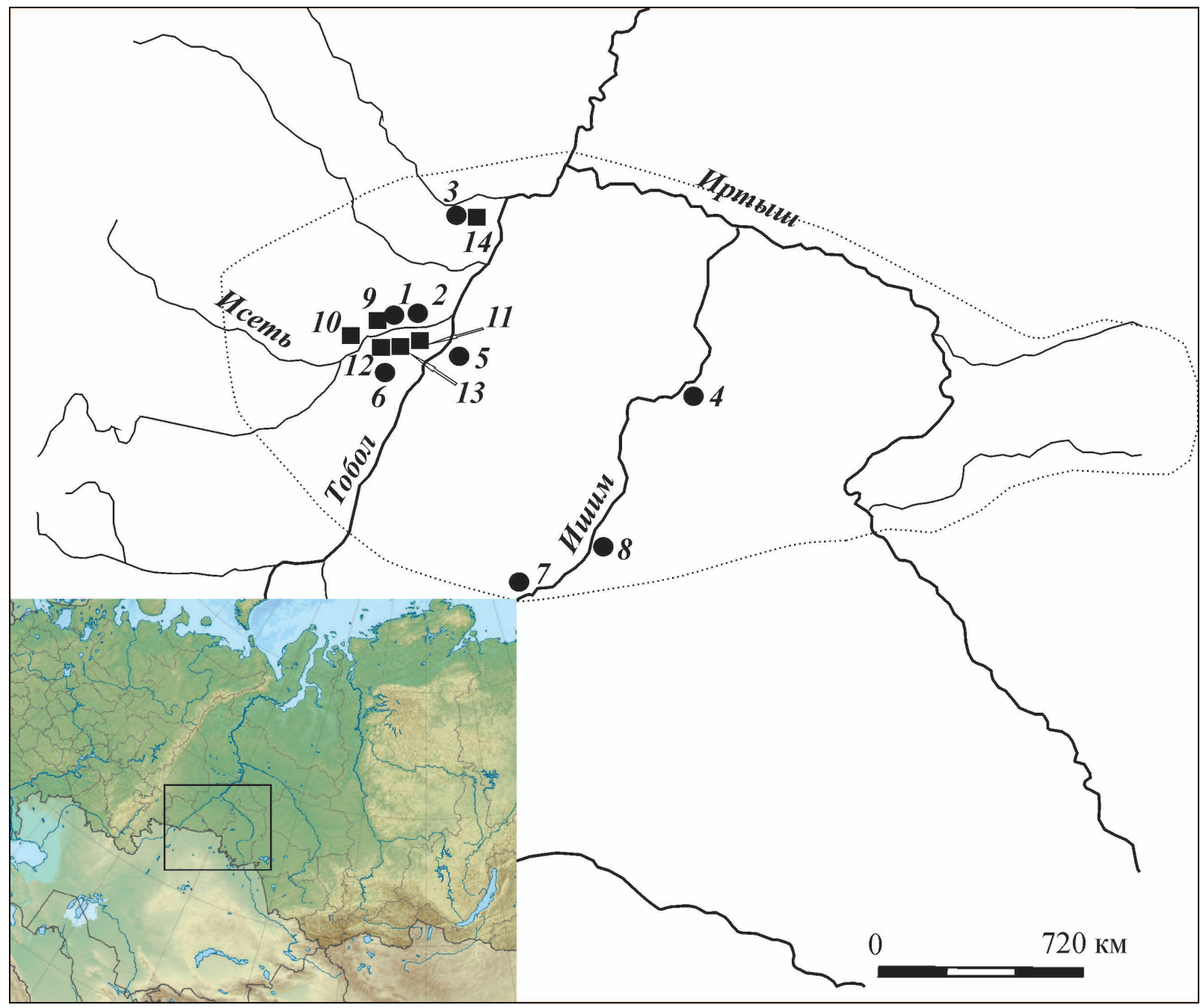

Рис. 1. Схема распространения древностей саргатской культуры и памятников, упоминаемых в статье:

Могильники: 1 - Сопининский $1 ; 2$ - Гаевский $1 ; 3$ - Ипкульский; 4 - Абатский 3 ; 5 - Савиновский; 6 - Тютринский; 7 - Покровский $1 ; 8$ - Явленка 1.

Городища: 9 - Павлиново; 10 - Прыговское; 11 - Большое Бакальское; 12 - Рафайловское; 13 - Коловское

Fig. 1. Map of the Sargat culture distribution and sites mentioned in the text:

Kurgan cemeteries: 1 - Sopininsky 1; 2 - Gaevsky 1; 3 - Ipkul'sky; 4 - Abatsky 3; 5 - Savinovsky; 6 - Tutrinsky; 7 - Pokrovsky; 8 - Yavlenka 1.

Fortresses: 9 - Pavlinovo; 10 - Prygovsky; 11 - Bol'she-Bakal'sky; 12 - Rafaylovsky; 13 - Kolovsky 


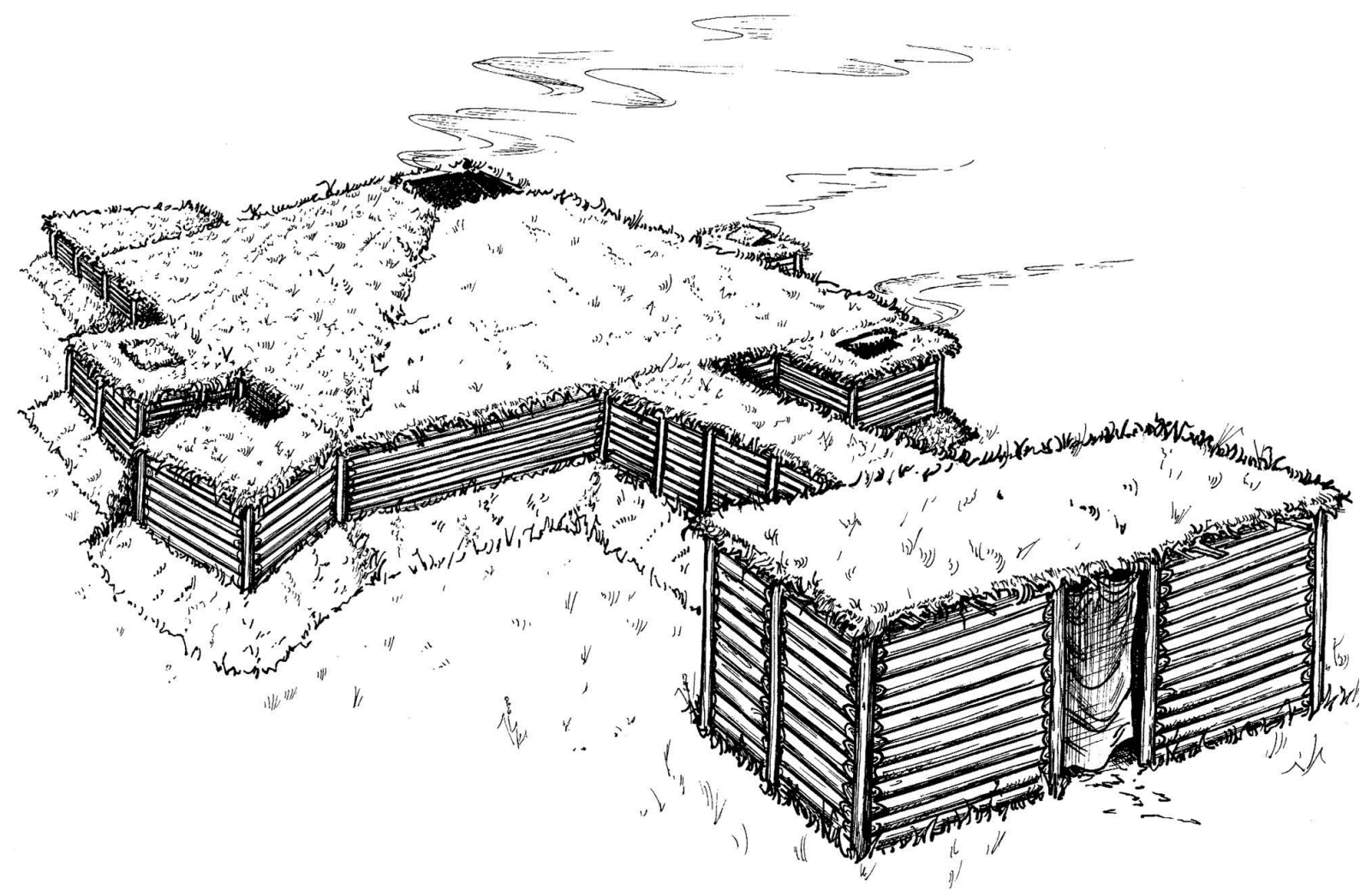

Рис. 2. Павлиново городище. Графическая реконструкция постройки 5 [Корякова и др., 2009, рис. 3.11]

Fig. 2. Pavlinovo fortress. Artistic reconstruction of house no. 5 [Koryakova et al., 2009, fig. 3.11] 


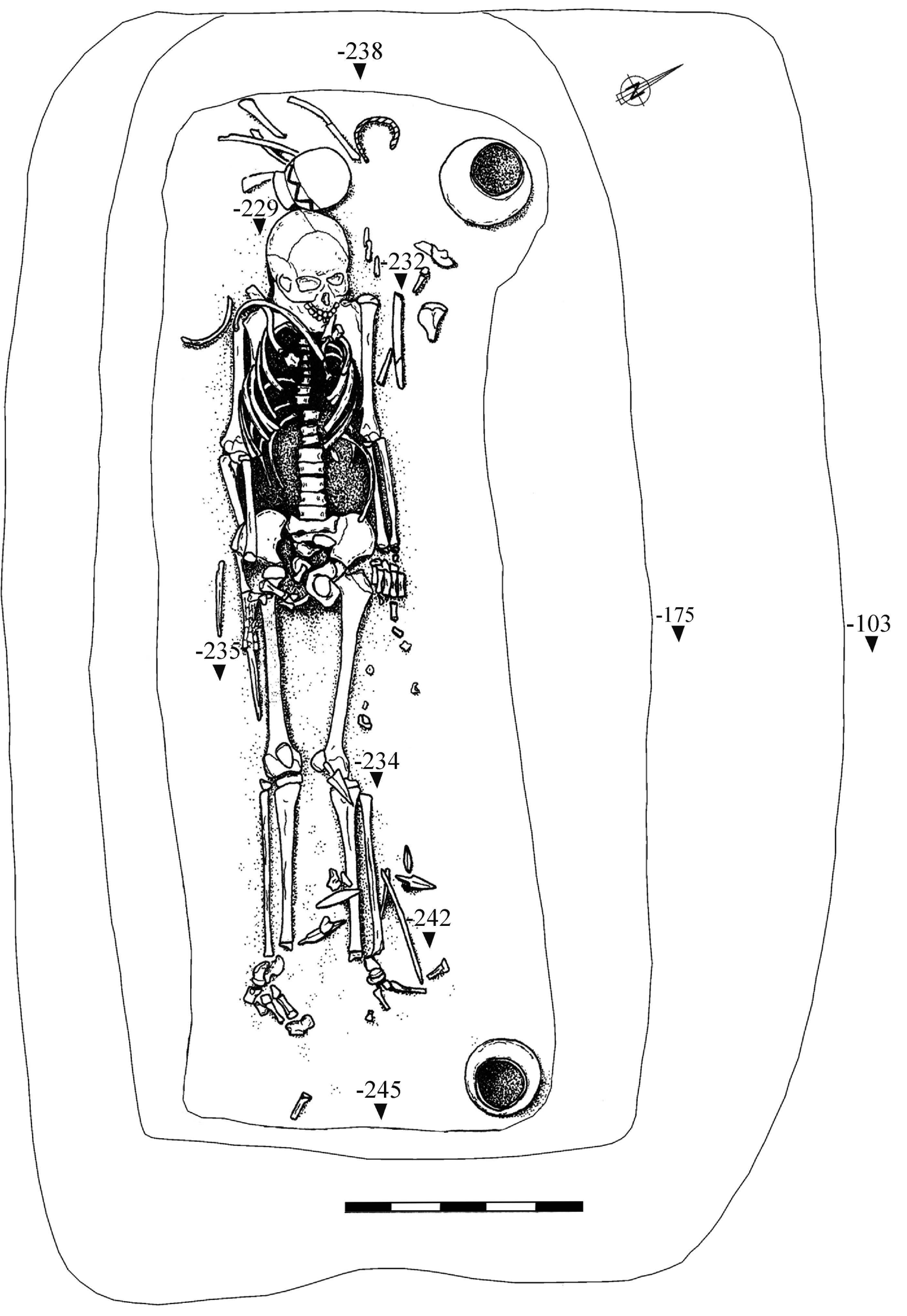

Рис. 3. Гаевский 1 могильник. Курган 6. Погребение 1 [Булдашев и др., 1997, рис. 16,2]

Fig. 3. Gaevsky 1 kurgan cemetery. Kurgan 6. Burial 1 [Buldashev et al., 1997, fig. 16,2] 


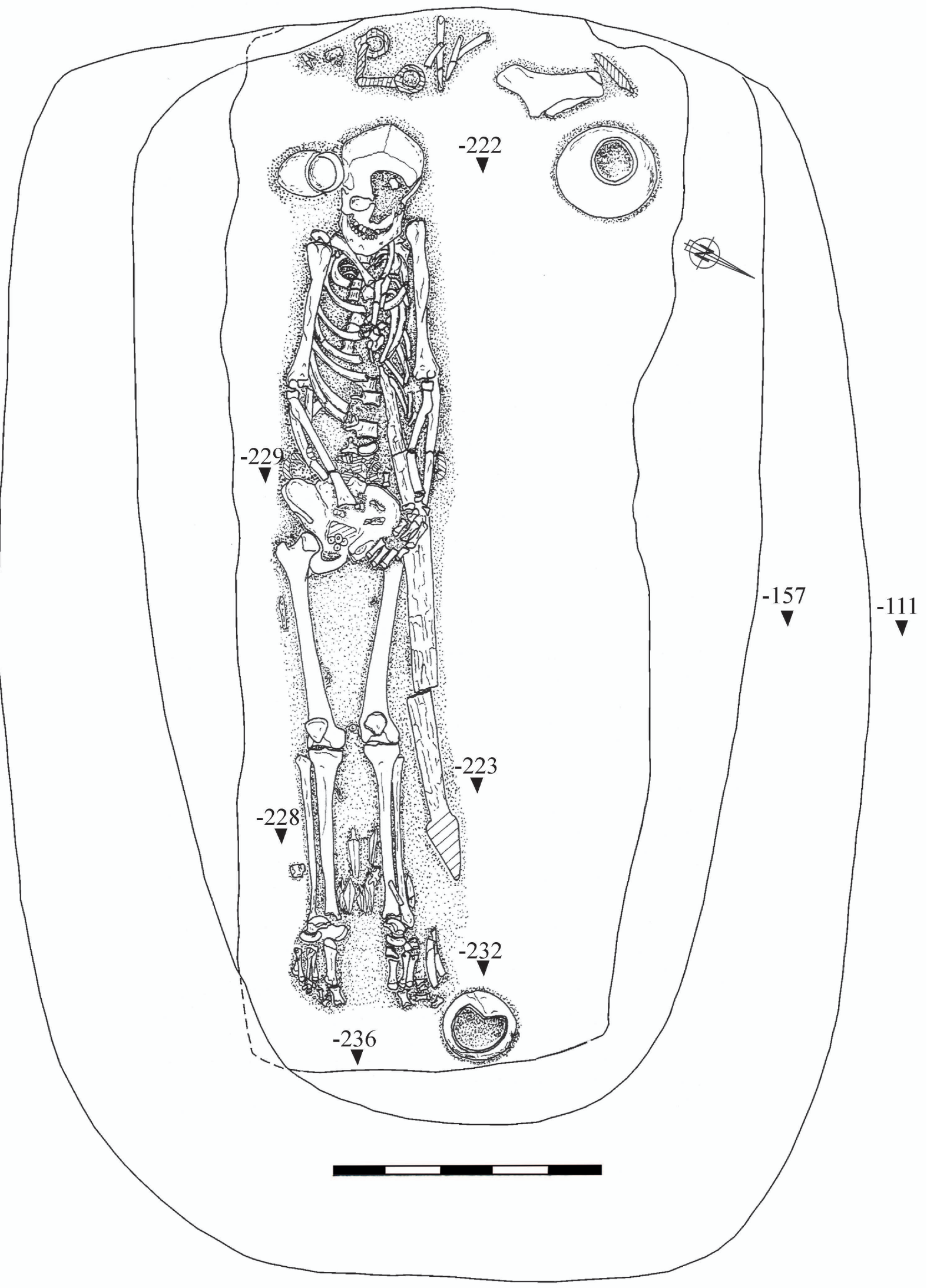

Рис. 4. Гаевский 1 могильник. Курган 6. Погребение 2 [Булдашев и др., 1997, рис. 17,4]

Fig. 4. Gaevsky 1 kurgan cemetery. Kurgan 6. Burial 2 [Buldashev et al., 1997, fig. 17,4] 
C.B. Шарапова. Верхняя хронологическая граница саргатской культуры

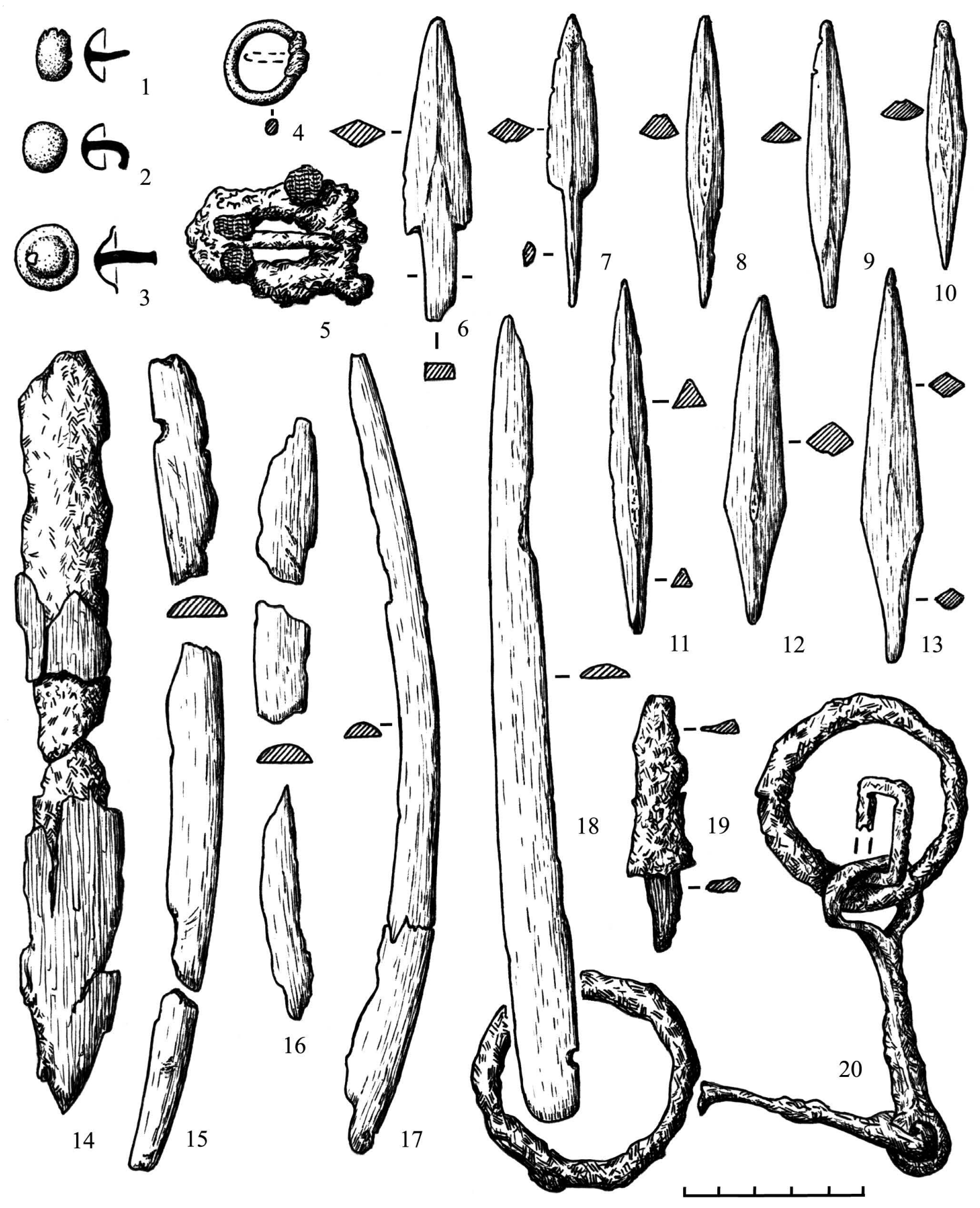

Рис. 5. Гаевский 1 могильник. Курган 6. Инвентарь погребения 1:

1-3 - бронза; 4- бронза, кожа; 5, 14, 19, 20 - железо; 6-13, 15-18- кость [Булдашев и др., 1997, рис. 18]

Fig. 5. Gaevsky 1 kurgan cemetery. Kurgan 6. Grave goods from burial 1:

1-3-bronze; 4-bronze, leather; 5, 14, 19, 20 - iron; 6-13, 15-18-bone [Buldashev et al., 1997, fig. 18] 


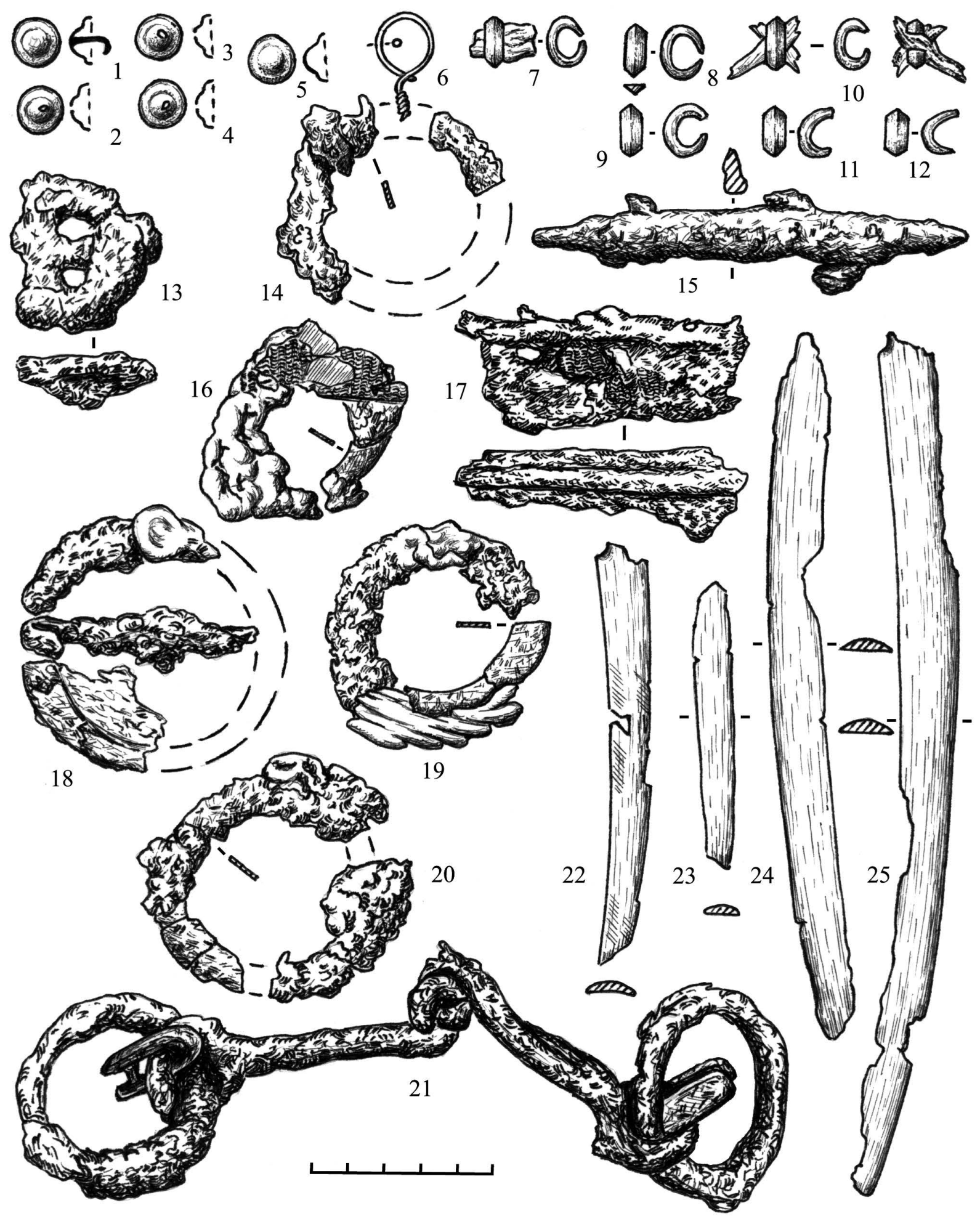

Рис. 6. Гаевский 1 могильник. Курган 6. Инвентарь погребения 2:

$1-5,8,9,11,12$ - бронза; 6 - бронза, серебро; 7-10 - бронза, кожа; 13-21 - железо; 22-25 - кость [Булдашев и др., 1997, рис. 19]

Fig. 6. Gaevsky 1 kurgan cemetery. Kurgan 6. Grave goods from burial 2:

$1-5,8,9,11,12$ - bronze; 6 - bronze, silver; $7-10$ - bronze, leather; $13-21$ - iron; 22-25 - bone [Buldashev et al., 1997, fig. 19] 


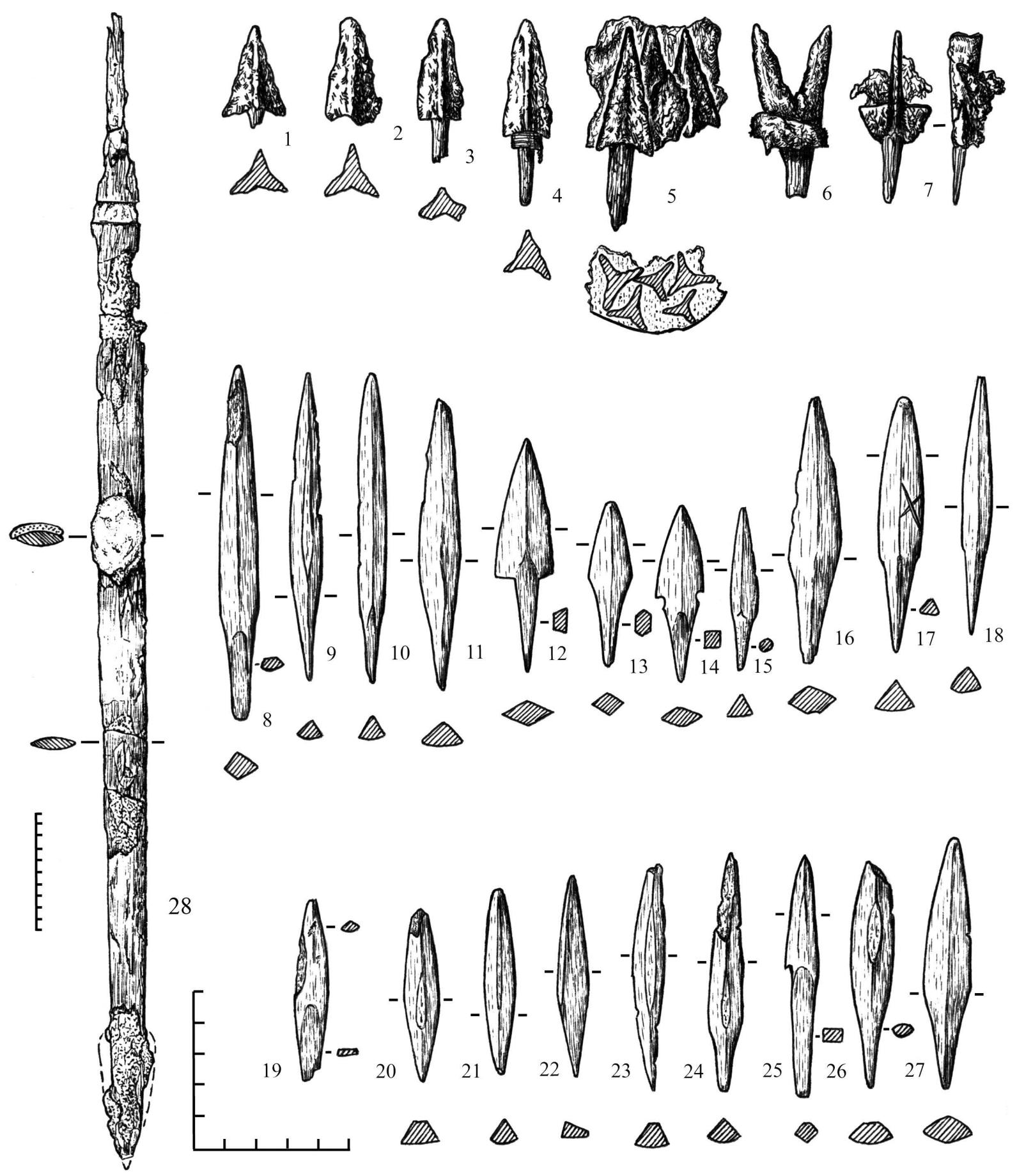

Рис. 7. Гаевский 1 могильник. Курган 6. Инвентарь погребения 2:

1-7, 28 - железо; 8-27 - кость [Булдашев и др., 1997, рис. 20, 21]

Fig. 7. Gaevsky 1 kurgan cemetery. Kurgan 6. Grave goods from burial 2:

1-7, 28 - iron; 8-27 - bone [Buldashev et al., 1997, fig. 20, 21] 


\section{СПИСОК ЛИТЕРАТУРЫ}

Алексеева Е. М., 1978. Античные бусы Северного Причерноморья. САИ. Вып. Г1-12. М. : Наука. 120 с.

Багашев А. Н., 2000. Палеоантропология Западной Сибири: лесостепь в эпоху раннего железа. Новосибирск : Наука. 374 с.

Берлина С. В., 2010. Жилая и оборонительная архитектура населения западносибирской лесостепи в раннем железном веке (по материалам саргатской культуры) : автореф. дис. ... канд. ист. наук. Тюмень. 18 с.

Боталов С. Г., 2016. Историко-культурные горизонты в эпоху раннего железного века и средневековья лесостепного Зауралья // Археология Южного Урала. Лес, лесостепь. Ранний железный век и средневековье (проблемы культурогенеза). Челябинск : Рифей. С. 468-531.

Боталов С. Г., Гуцалов С. Ю., 2000. Гунно-сарматы Урало-Казахстанских степей. Челябинск : Рифей. 267 с.

Боталов С. Г., Тидеман Е. В., Лукиных А. А., Вохменцев М. П., 2008. Новые материалы исследований Большого Бакальского городища // Проблемы бакальской культуры. Челябинск ; Шадринск : Рифей. С. 6-44.

Булдашев В. А., Ковригин А. А., Корякова Л. Н., Косинцев П. А., Курто П., Махонина Г. И., Ражев Д. И., Потро Ж.-П., Шарапова С. В., 1997. Культура зауральских скотоводов на рубеже эр. Гаевский могильник саргатской общности: антропологическое исследование. Екатеринбург : Екатеринбург. 180 с.

Бурков С. Б., 2014. Амулеты и талисманы из «египетского фаянса» с территории Осетии // Народы Кавказа: история, этнология, культура. К 60-летию со дня рождения В.С. Уарзиати : материалы Всерос. науч. конф. с междунар. участием. Владикавказ : ИПЦ СОИГСИ ВНЦ РАН и РСО-А. С. 177-186.

ван дер Плихт Й., Шишлина Н. И., Зазовская Э. П., 2016. Радиоуглеродное датирование: хронология археологических культур и резервуарный эффект. Труды ГИМ. Вып. 203. М. : Палеограф. 112 с.

Граков Б. Н., 1977. Ранний железный век (культуры Западной и Юго-Западной Европы). М. : Изд-во МГУ. 235 с. Гущина И. И., Засецкая И. П., 1994. «Золотое кладбище» римской эпохи в Прикубанье. СПб. : Фарн. 172 с.

Довгалюк Н. П., 1995. Стеклянные украшения Западной Сибири эпохи раннего железного века (по материалам саргатской культуры) : автореф. дис. ... канд. ист. наук. М. 18 с.

Зыков А. П., 2012. Барсова Гора: очерки археологии Сургутского Приобья. Средневековое и новое время. Екатеринбург : Уральский рабочий. $232 \mathrm{c}$.

Зыков А. П., Косинцев П. А., Трепавлов В. В., 2017. Город Сибир - городище Искер (историко-археологическое исследование). М. : Наука : Восточная литература. 559 с.

Зыков А. П., Федорова Н. В., 2001. Холмогорский клад: коллекция древностей III-IV веков из собрания Сургутского художественного музея. Екатеринбург : Сократ. $176 \mathrm{c.}$

Клейн Л. С., 2012. Археологическое исследование: методика кабинетной работы археолога. В 2 кн. Донецк : Изд-во Донец. нац. ун-та. Кн. $1-622$ с. ; Кн. 2 - 599 с.

Ковригин А. А., 2007. К датировке Абатского 3 могильника // XVII Уральское археологическое совещание : материалы науч. конф. Екатеринбург ; Сургуг : Магеллан. С. 194-198.

Ковригин А. А., Корякова Л. Н., Курто П., Ражев Д. И., Шарапова С. В., 2006. Аристократические погребения из могильника Карасье 9 // Южный Урал и сопредельные территории в скифо-сарматское время : сб. ст. к 70-летию А.Х. Пшеничнюка. Уфа : Гилем. С. 187-203.

Ковригин А. А., Шарапова С. В., 1998. Культурно-хронологические комплексы Прыговского городища // Взаимодействие саргатских племен с внешним миром. Омск : Изд-во Ом. гос. ун-та. С. 47-53.

Корякова Л. Н., 1988. Ранний железный век Зауралья и Западной Сибири (саргатская культура). Свердловск : Изд-во Урал. ун-та. 240 с.

Корякова Л. Н., 1991. Культурно-исторические общности Урала и Западной Сибири (Тоболо-Иртышская провинция в начале железного века). Екатеринбург : Изд-во ИИиА УрО РАН. 52 с.

Корякова Л. Н., 1994а. Поселения и жилища Тоболо-Иртышской лесостепи // Очерки культурогенеза народов Западной Сибири. Т. 1, кн. 1 : Поселения и жилища. Томск : Изд-во Том. ун-та. С. 259-275.

Корякова Л. Н., 1994б. Урало-Иртышская лесостепь // Очерки культурогенеза народов Западной Сибири. Т. 2 : Мир реальный и потусторонний. Томск : Изд-во Том. ун-та. С. 113-169.

Корякова Л. Н., Морозов В. М., Суханова Т. Ю., 1988. Поселение Ипкуль XV- памятник переходного периода от раннего железного века к средневековью в Нижнем Притоболье // Материальная культура древнего населения. Свердловск : Изд-во УрГУ. С. 117-129. 
Корякова Л. Н., Дэйр М.-И., Ковригин А. А., Шарапова С. В., Берсенева Н. А., Пантелеева С. Е., Ражев Д. И., Курто П., Хэнкс Б., Ефимова Е. Г., Каздым А. А., Микрюкова О. В., Сахарова А. О., 2009. Среда, культура и общество лесостепного Зауралья во второй половине I тыс. до н.э. (по материалам Павлиновского археологического комплекса). Екатеринбург ; Сургут : Магеллан. 298 с.

Корякова Л. Н., Шарапова С. В., Ковригин А. А., 2010. Прыговский 2 могильник: кочевники и лесостепь // Уральский исторический вестник. № 2 (27). С. 62-71.

Косинцев П. А., Корякова Л. Н., Валдайских В. В., Иванов И. В., Каздым А. А., Корона О. М., Махонина Г. И., Панова Н. К., Табанакова Е. Д., Хэнкс Б., 2003. Комплексные исследования Павлиновского городища // Экология древних и современных обществ : материалы конф. Вып. 2. Тюмень : ИПОС СО РАН. C. 132-139.

Кривошеев М. В., Борисов А. В., 2019. Климатический оптимум как фактор кризиса экономики степных номадов // Вестник ВолГУ. Серия 4, История. Регионоведение. Международные отношения. Т. 24 , № 3. C. 47-57. DOI: https://doi.org/10.15688/jvolsu4.2019.3.4.

Кызласов Л. Р., 1955. Сырский Чаа-Тас // Советская археология. № XXIV. С. 197-256.

Левина Л. М., 1996. Этнокультурная история Восточного Приаралья. І тысячелетие до н.э. - I тысячелетие н.э. М. : Восточная литература. 396 с.

Максименко В. Е., Безуглов С. И., 1987. Позднесарматские погребения на р. Быстрой // Советская археология. № 1. C. 183-192.

Малашев В. Ю., 2000. Периодизация ременных гарнитур позднесарматского времени // Сарматы и их соседи на Дону. Ростов н/Д : Терра. С. 194-232.

Малашев В. Ю., 2009. Позднесарматская культура: верхняя хронологическая граница // Российская археология. № 1. С. 47-52.

Малашев В. Ю., 2013. Позднесарматская культура Южного Приуралья во II-III вв. н. э. : автореф. дис. ... канд. ист. наук. М. 25 с.

Малашев В. Ю., 2016. Памятники среднесарматской культуры северокавказских степей и их традиции в курганных могильниках Северо-Восточного Кавказа второй половины II - середины V в. н.э. М. : ИА PAH. 208 c.

Малашев В. Ю., Мошкова М. Г., 2010. Происхождение позднесарматской культуры (к постановке проблемы) // Становление и развитие позднесарматской культуры (по археологическим и естественнонаучным данным) : материалы семинара Центра изучения истории и культуры сарматов. Вып. III. Волгоград : Изд-во ВолГУ. С. 37-56.

Малашев В. Ю., Яблонский Л. Т., 2008. Степное население Южного Приуралья в позднесарматское время: по материалам могильника Покровка 10. М. : Восточная литература. 365 с.

Марсадолов Л. С., 2016. Проблемы объяснения ряда «искажающих эффектов» при радиоуглеродном датировании археологических объектов // Экология древних и традиционных обществ : материалы V Междунар. науч. конф. Вып. 5, ч. 2. Тюмень : Изд-во ТюмГУ. С. 107-113.

Маслов В. Е., 2018. К вопросу о происхождении поясных накладок со сценой охоты из Сибирской коллекции Петра I // Краткие сообщения Института археологии. Вып. 250. С. 25-42. DOI: http://doi.org/10.25681/ IARAS.0130-2620.250.25-42.

Матвеев А. В., Матвеева Н. П., 1991. Савиновский могильник саргатской культуры. Итоги полевых исследований. Тюмень : ИПОС СО РАН. 53 с.

Матвеева Н. П., 1993а. Рафайловское городище - памятник саргатской культуры Среднего Притоболья // Российская археология. № 1. С. 148-163.

Матвеева Н. П., 1993б. Саргатская культура на Среднем Тоболе. Новосибирск : Наука. 175 с.

Матвеева Н. П., 1994. Ранний железный век Приишимья. Новосибирск : Наука. 152 с.

Матвеева Н. П., 2000. Социально-экономические структуры населения Западной Сибири в раннем железном веке. Новосибирск : Наука. 399 с.

Матвеева Н. П., 2017. Радиоуглеродная хронология памятников саргатской культуры (Западная Сибирь) // Российская археология. № 4. С. 3-20.

Матвеева Н. П., Берлина С. В., Рафикова Т. Н., 2008. Коловское городище. Древности Ингальской долины: Археолого-палеоэкологическое исследование. Вып. 2. Новосибирск : Наука. 240 с. 
Матвеева Н. П., Зеленков А. С., 2018. О западносибирских инвазиях в Приуралье в эпоху Великого переселения народов // Вестник Пермского университета. История. Вып. 1 (40). C. 71-86. DOI: http://doi.org/ 10.17072/2219-3111-2018-1-71-85.

Матвеева Н. П., Ларина Н. С., Берлина С. В., Чикунова И. Ю., 2005. Комплексное изучение условий жизни древнего населения Западной Сибири (проблемы социокультурной адаптации в раннем железном веке). Новосибирск : Изд-во СО РАН. 228 с.

Миняев С. С., Елихина Ю. И., 2010. К хронологии курганов Ноин-Улы // Записки ИИМК РАН. СПб. : Дмитрий Буланин. Вып. 5. С. 169-182.

Могильников В. А., 1972. К вопросу о саргатской культуре // Проблемы археологии и древней истории угров. М. : Наука. С. 66-86.

Могильников В. А., 1987. Лесостепное Зауралье (бакальская культура) // Финно-угры и балты в эпоху средневековья. Археология СССР. М. : Наука. С. 179-183.

Могильников В. А., 1992а. Лесостепь Зауралья и Западной Сибири // Степная полоса Азиатской части СССР в скифо-сарматское время. Археология СССР. М. : Наука. С. 274-311.

Могильников В. А., 1992б. Хунну Забайкалья // Степная полоса Азиатской части СССР в скифо-сарматское время. Археология СССР. М. : Наука. С. 254-273.

Мошкова М. Г., 1989а. Среднесарматская культура // Степи европейской части СССР в скифо-сарматское время. Археология СССР. М. : Наука. С. 177-191.

Мошкова М. Г., 1989б. Позднесарматская культура // Степи европейской части СССР в скифо-сарматское время. Археология СССР. М. : Наука. С. 191-202.

Мошкова М. Г., Генинг В. Ф., 1972. Абатские курганы и их место среди лесостепных культур Зауралья и Западной Сибири // Памятники Южного Приуралья и Западной Сибири сарматского времени. МИА. № 153. М. : Наука. С. 87-118.

Пилипенко А. С., Черданцев С. В., Трапезов Р. О., Молодин В. И., Кобелева Л. С., Поздняков Д. В., Полосьмак Н. В., 2017. Палеогенетическое исследование родства погребенных из курганов саргатской культуры в Барабинской лесостепи (Западная Сибирь) // Археология, этнография и антропология Евразии. № 45 (4). C. 132-142. DOI: https://doi.org/10.17746/1563-0102.2017.45.4.132-142.

Полосьмак Н. В., 1987. Бараба в эпоху раннего железа. Новосибирск : Наука. 144 с.

Ражев Д. И., 2009. Биоантропология населения саргатской общности. Екатеринбург : УрО РАН. 492 c.

Ражев Д. И., Ковригин А. А., 1999. Курганные могильники саргатской культуры и социально-демографическая структура древнего общества // Экология древних и средневековых обществ : тез. докл. конф., посвящ. 275-летию РАН. Тюмень : ИПОС СО РАН. С. 171-175.

Рафикова Т. Н., 2011. Бакальская культура лесостепного и подтаежного Тоболо-Ишимья : автореф. дис. ... канд. ист. наук. Тюмень. 19 с.

Сальников К. В., 1956. Исетские древние поселения // Советская археология. № 25. С. 189-215.

Смирнов К. Ф., Попов С. А., 1972. Савромато-сарматские курганы у с. Липовка Оренбургской области // Памятники Южного Приуралья и Западной Сибири сарматского времени. Материалы и исследования по археологии СССР. № 153. М. : Наука. С. 3-26.

Сорокин С. С., 1977. Погребения эпохи великого переселения народов в районе Пазырыка // Археологический сборник Государственного Эрмитажа. Л. : Аврора. Вып. 18. С. 57-67.

Стоянов В.Е., 1970. Классификация и периодизация западносибирских лесостепных памятников раннего железного века // Проблемы хронологии и культурной принадлежности археологических памятников Западной Сибири. Томск : Изд-во Том. ун-та. С. 238-253.

Хазанов А. М., 1963. Генезис сарматских бронзовых зеркал // Советская археология. № 9. С. 58-71.

Хазанов А. М., 1971. Очерки военного дела сарматов. М. : Наука. 172 с.

Чикунова И. Ю., 2017. Ипкульский курганный могильник (результаты раскопок 2010-2011 гг.) // ABORIGIN: археолого-этнографический сборник. Вып. 9. Тюмень : Изд-во ТюмГУ. С. 79-110.

Шарапова С. В., 2000. Керамика раннего железного века лесостепного Зауралья (опыт статистического анализа) : автореф. дис. ... канд. ист. наук. Ижевск. 27 с.

Шарапова С. В., 2018. Биоархеология населения лесостепного Зауралья и Западной Сибири (саргатская культура) // Stratum Plus. № 3. C. 323-350. 
Шарапова С. В., Пилипенко А. С., Ражев Д. И., Трапезов Р. О., Черданцев С. В., 2020. Два мужских погребения из кургана саргатской культуры: биоархеологический и палеогенетический обзор // Stratum Plus. № 3. C. 379-404.

Akhmedov I., 2007. Le harnachement de Tsibilium. A propos de la formation du type "pontique" de harnachement de l'époque des Grandes Migration // Kazanski M., Mastykova A. Tsibilium. La nécropole apsile de Tsibilium. Ĺ étude du site. Vol. 2. Oxford (BAR International Series S1721). P. 67-72.

Bronk Ramsey C., 2017. OxCal 4.3. URL: http://c14.arch.ox.ac.uk (accessed 10 Sept. 2019).

Daire M.-Y., Koryakova L., Buldashov V., Courtaud P., Epimajov A., Gonzalez E., Kovrigin A., Kosintsev P., Langouet L., Makhonina G., Marguerie D., Pautreau J.-P., Rajev D., Sharapova S., Uge M.-C., 2002. Habitats et necropolis de l'Age du Fer au Carrefour de l'Eurasie. Les fouilles de 1993 à 1997. Memoires de la mission archeologique francaise en Asie Centrale. Tome XI. Paris : Diffusion de Broccard. 291 p.

Reimer P. J., Bard E., Bayliss A., 2013. IntCal13 and Marine13 radiocarbon age calibration curves 0-50,000 years cal BP// Radiocarbon. № 55 (4). P. 1869-1887.

\section{REFERENCES}

Alexeeva E.M., 1978. Antichnye busy Severnogo Prichernomor'ya [Antic Beads of the Northern Black Sea Region]. Svod Arkheologicheskih Istochnikov, iss. Г1-12. Moscow, Nauka Publ. 120 p.

Bagashev A.N., 2000. Paleoatropologiya Zapadnoy Sibiri: lesostep'v epokhu rannego zheleza [Paleoanthropology of the Western Siberia: Forest-Steppe During Iron Age]. Novosibirsk, Nauka Publ. 374 p.

Berlina S.V., 2010. Zhilaya i oboronitel'naya arkhitektura naseleniya zapadnosibirskoi lesostepi $v$ rannem zheleznom veke (po materialam sargatskoi kultury): avtoref. dis. ... kand. ist. nauk [Living and Defensive Architecture of the West Siberian Population During the Iron Age (Based on Materials of the Sargat Culture). Cand. hist. sci. abs. diss.]. Tumen. 18 p.

Botalov S.G., 2016. Istoriko-kul'turnye gorizonty v epokhu rannego zheleznogo veka i srednevekov'ya lesostepnogo Zaural'ya [Historical-Cultural Horizons During the Iron and Middle Ages in Forest-Steppe Trans-Urals]. Arkheologiya Yuzhnogo Urala. Les, lesostep'. Rannii zheleznyi vek i srednevekovie (problemy kul'turogeneza) [Archaeology of the Southern Urals. Forest, Forest-Steppe. Early Iron and Middle Ages (Problems of the Culturegenesis)]. Chelyabinsk, Rifey Publ., pp. 468-531.

Botalov S.G., Gutsalov S.Yu., 2000. Gunno-sarmaty Uralo-Kazakhstanskikh stepey [Hun-Sarmatians of the UralKazakhstan Steppe]. Chelyabinsk, Rifey Publ. 267 p.

Botalov S.G., Tideman E.V., Lukinykh A.A., Vokhmentsev M.P., 2008. Novye materialy issledovaniy Bolshogo Bakal'skogo gorodischa [New Materials of the Bol'shoy Bakal'sky Fortress Investigation]. Problemy bakal'skoi kultury [Bakal'skaya Culture Problems]. Chelyabinsk; Shadrinsk, Rifey Publ., pp. 6-44.

Buldashev V.A., Kovrigin A.A., Koryakova L.N., Kosintsev P.A., Courtaud P., Makhonina G.I., Razhev D.I., Pautreau J.-P., Sharapova S.V., 1997. Kul'tura zaural'skikh skotovodov na rubezhe er. Gaevsky mogil'nik sargatskoy obschnosti: antropologicheskoye issledovanie [The Culture of Trans-Uralian Cattle and Horse Breeders on the Turn of Erae. The Gayevsky Burial Ground of the Sargat Entity: Anthropological Research]. Ekaterinburg, Ekaterinburg Publ. 180 p.

Burkov S.B., 2014. Amulety i talismany iz «egipetskogo fayansa» s territorii Osetii [Amulets and Mascots Made of "Egyptian Faience" in Ossetia]. Narody Kavkaza: istoriya, etnologiya, kul'tura. K 60-letiyu so dnya rozhdeniya V.S. Uarziati: materialy Vseros. nauch. konf. s mezhdunar. uchastiem [Population of the Caucasus: History, Ethnology, Culture. On 60-s Anniversary of V.S. Uarziati. Proceedings of the International Conference]. Vladikavkaz, RAS Publ., pp. 177-186.

van der Plicht J., Shishlina N.I., Zazovskaya E.P., 2016. Radiouglerodnoye datirovanie: khronologiya arkheologicheskokh kul tur i rezervuarnyi effect [Radiocarbon Dating: Chronology of Archaeological Cultures and Reservoir Effect]. Trudy Gosudarstvennogo Istoricheskogo Museya [Proceedings of the State Historical Museum], iss. 203. Moscow, Paleograph Publ. 112 p.

Grakov B.N., 1977. Ranniy zhelezhnyy vek (kultury Zapadnoy i Yugo-Zapadnoy Evropy) [Early Iron Age (Cultures of the West and South-West Europe)]. Moscow, MSU. 235 p.

Guschina I.I., Zasetskaya I.P., 1994. «Zolotoe kladbische» rimskoy epokhi v Prikubanye [“Golden Cemetery” of the Roman Time in the Kuban Region]. Saint Petersburg, Farn Publ. 172 p. 
Dovgalyuk N.P., 1995. Steklyannye ukrasheniya Zapadnoy Sibiri epokhi rannego zheleznogo veka (po materialam sargatskoi kul'tury): avtoref. dis. ... kand. ist. nauk [Glass Decoration of the West Siberia During the Early Iron Age (Based on Materials of the Sargat Culture). Cand. hist. sci. abs. diss.]. Moscow. 18 p.

Zykov A.P., 2012. Barsova Gora: ocherki arkheologii Surgutskogo Priob'ya. Srednevekovoe i novoe vremya [Barsova Gora: Essay on Archaeology of the Ob’ River Basin at Surgut. Medieval and New Ages]. Ekaterinburg, Uralskiy Rabochiy Publ. 232 p.

Zykov A.P., Kosintsev P.A., Trapavlov V.V., 2017. Gorod Sibir - gorodische Isker (istoriko-arkheologicheskoe issledovanie) [Fort of Sibir - Isker Fortress (Historical-Archaeological Research)]. Moscow, Nauka Publ. 559 p.

Zykov A.P., Fedorova N.V., 2001. Kholmogorsky klad: kollekrsiya drevnostei III-IV vekov iz sobraniya Surgutskogo khudozhestvennogo museya [Kholmogory Treasure: Collection of the III-IV Centuries Antiquities from Surgut Fine Art Museaum]. Ekaterinburg, Sokrat Publ. 176 p.

Klein L.S., 2012. Arkheologicheskoe issledovanie: metodika kabinetnoi raboty arkheologa. V 2 kn. [Archaeological Research: Methods of the Desk-Top Work of an Archaeologist. In 2 vols]. Donetsk, DNU. Vol. 1. 622 p.; vol. 2. 599 p.

Kovrigin A.A., 2007. K datirovke Abatskogo 3 mogil'nika [About Dating of the Abatsky 3 Cemetery]. XVII Ural'skoe arkheologicheskoe soveschanie: materialy nauch. konf. [XVII Urals Archaeological Meeting. Proceedings of the Scientific Conference]. Ekaterinburg; Surgut, Magellan Publ., pp. 194-198.

Kovrigin A.A., Koryakova L.N., Courtaud P., Razhev D.I., Sharapova S.V., 2006. Aristokraticheskie pogrebeniya iz mogil'nika Karasie 9 [Aristocratic Burials in Karasie 9 Cemetery]. Yuzny Ural i sopredel'nye territorii $v$ skifosarmatskoe vremya: sb. st. $k$ 70-letiyu A.Kh. Pshenichnyuka [Southern Urals and Outside Territories in Scythian-Sarmatian Ages: Articles to 70 Anniversary of A.Kh. Pshenichnyuk]. Ufa, Gilem Publ., pp. 187-203.

Kovrigin A.A., Sharapova S.V., 1998. Kulturno-khronologicheskie compleksy Prygovskogo gorodischa [CulturalChronological Complexes of the Prygovsky Fortress]. Vzaimodeistvie sargatskikh plemen s vneshnim mirom [Interaction of the Sargat Tribes with Outside World]. Omsk, OSU, pp. 47-53.

Koryakova L.N., 1988. Ranny zhelezny vek Zaural'ya i Zapadnoy Sibiri (sargatskaya kul 'tura) [Early Iron Age of the Trans-Urals and Western Siberia (Sargat Culture). Sverdlovsk, Ural State University. 240 p.

Koryakova L.N., 1991. Kul 'turno-istoricheskie oschnosti Urala i Zapadnoy Sibiri (Tobolo-Irtyshskaya provintsiya $v$ nachale zheleznogo veka) [Kultural and Historical Groups of the Urals and Western Siberia (Tobol and Irtysh Rivers Basin During the Beginning of the Iron Age)]. Ekaterinburg, RAS Publ. 52 p.

Koryakova L.N., 1994a. Poseleniya I Zhilischa Tobolo-Irtyshskoy lesostepi [Settlements and Dwellings of TobolIrtysh Forest-Steppes]. Ocherki kulturogeneza narodov Zapadnoy Sibiri. T. 1, kn. 1: Poseleniya i zhilischa [Essays on the Cultural Genesis of the Peoples of Western Siberia. Vol. 1, book 1: Settlements and Dwellings]. Tomsk, TSU, pp. 259-275.

Koryakova L.N., 19946. Uralo-Irtyshskaya lesostep [Ural-Irtysh Forest-Steppes]. Ocherki kulturogeneza narodov Zapadnoy Sibiri. T. 2: Mir realnyy i potustoronniy [Essays on the Cultural Genesis of the Peoples of Western Siberia. Vol. 2: Real World and the Beyond]. Tomsk, TSU, pp. 113-169.

Koryakova L.N., Morozov V.M., Sukhanova T.Yu., 1988. Poselenie Ipkul' XV - pamyatnik perekhodnogo perioda ot rannego zheleznogo veka k srednevekov'u v Nizhnem Pritobol'e [Ipkul' XV Settlement - Site of the Transition Period from Early Iron to Middle Ages in Low Tobol River Basin]. Materialnaya kul 'tura drevnego naseleniya [Material Culture of the Ancient Population]. Sverdlovsk, Ural State University, pp. 117-129.

Koryakova L.N., Daire M.-I., Kovrigin A.A., Sharapova S.V., Berseneva N.A., Panteleeva S.E., Razhev D.I., Courtaud P., Hanks B., Efimova E.G., Kazdym A.A., Mikryukova O.V., Sakharova A.O., 2009. Sreda, kul tura i obschestvo lesostepnogo Zaural'ya vo vtoroy polovine I tys. do n.e. (po materialam Pavlinovskogo arkheologicheskogo kompleksa) [Environment, Culture and Society of the Forest-Steppe Trans-Urals During I Millennium BC (Based on Materials of the Pavlinovo Archaeological Complex)]. Ekaterinburg; Surgut, Magellan Publ. 298 p.

Koryakova L.N., Sharapova S.V., Kovrigin A.A., 2010. Prygovsky 2 mogil'nik: kochevniki i lesostep' [Prygovsky 2 Burial Ground: Nomads and Forest-Steppe]. Ural'sky istorichesky vestnik [Ural Historical Journal], no. 2 (27), pp. 62-71.

Kosintsev P.A., Koryakova L.N., Valdaiskikh V.V., Ivanov I.V., Kazdym A.A., Korona O.M., Makhonina G.I., Panova N.K., Tabanakova E.D., Hanks B., 2003. Kompleksnye issledovaniya Pavlinovskogo gorodischa [Complex Investigation of the Pavlinovsky Fortress]. Ekologiya drevnikh i sovremennykh obschestv: materialy konf. [Ecology of the Past and Modern Societies. Proceedings of the Conference], iss. 2. Tumen', Institute of the Problems of Northern Developments Siberian Branch of RAS, pp. 132-139. 
Krivosheev M.V., Borisov A.V., 2019. Klimaticheskiy optimum kak factor krizisa ekonomiki stepnykh nomadov [Climatic Optimum as a Factor of the Economic Crisis of Steppe Nomads in the $4^{\text {th }}$ Century AD]. Science Journal of VolSU. History. Area Studies. International Relations, vol. 24. no. 3, pp. 47-57. DOI: https:// doi.org/10.15688/jvolsu4.2019.3.4.

Kyzlasov L.R., 1955. Syrskiy Chaa-Tas [Syrsky Chaa-Tas]. Sovetskaya arkheologiya [Soviet Archaeology], no. XXIV, pp. 197-256.

Levina L.M., 1996. Etnokul 'turnaya istoriya Vostochnogo Priaral'ya. I tysyacheletie do n.e. - I tysyacheletie n.e. [Ethnocultural History of East Aral See. I millennium BC - I millennium AD]. Moscow, Vostochnaya literatura Publ. 396 p.

Maksimenko V.E., Bezuglov S.I., 1987. Pozdnesarmatskie pogrebeniya na r. Bystroy [Late Sarmatian Burials in the Mounds Along the Bystraya River]. Sovetskaya arkheologiya [Soviet Archaeology], no. 1, pp. 183-192.

Malashev V.Yu., 2000. Pereodizatsiya remennykh garnitur pozdnesarmatskogo vremeni [Periodization of Belt Gear of the Late Sarmatian Age]. Sarmaty i ikh sosedy na Donu [Sarmatians and Their Neighbors at Don River Basin]. Rostov-na-Donu, Terra Publ., pp. 194-232.

Malashev V.Yu., 2009. Pozdnesarmatskaya kul'tura: verkhnyaya khronologicheskaya granitsa [Late Sarmatian Culture: Upper Chronological Boundary]. Rossiyskaya arkheologiya [Russian Archaeology], no. 1, pp. 47-52.

Malashev V.Yu., 2013. Pozdnesarmatskaya kul'tura Yuzhnogo Priural'ya vo II-III vv. n.e.: avtoref. dis. ... kand. ist. nauk [Late Sarmatian Culture of the Southern Cis-Urals During II-III Centuries AD. Cand. hist. sci. abs. diss.]. Moscow. 25 p.

Malashev V.Yu., 2016. Pamyatniki srednesarmatskoy kultury severokavkazskikh stepei $i$ ikh traditsii $v$ kurgannykh mogil'nikakh Severo-Vostochnogo Kavkaza vtoroy poloviny II-serediny Vv. n.e. [Sites of the Mid Sarmatian Culture in North Caucasus Steppe and its Traditions in Kurgan Cemeteries in NorthEastern Caucasus During Second Half of the II - Mid V Centuries AD]. Moscow, Institute of Archaeology Publ. 208 p.

Malashev V.Yu., Moshkova M.G., 2010. Proiskhozhdenie pozdnesarmatskoy kul'tury (k postanovke problemy) [Origin of Late Sarmatian Culture (Formulation of a Problem)]. Stanovlenie i razvitie pozdnesarmatskoy kultury (po arkheologicheskim i estestvennonauchnym dannym): materialy seminara Tsentra izucheniya istorii i kultury sarmatov. Vyp. III [The Formation and Development of the Late Sarmatian Culture (Based on Archaeological and Natural Science Data): Materials of the Seminar of the Center for Studying History and Culture of the Sarmatians. Iss. 3]. Volgograd, VolSU, pp. 37-56.

Malashev V.Yu., Yablonsky L.T., 2008. Stepnoe naselenie Yuzhnogo Priural'ya v pozdnesarmatskoe vremya: po materialam mogil'nika Pokrovka 10 [The Steppe Population of the South Urals Area in the Late Sarmatian Time: On the Materials from Pokrovka 10 Cemetery]. Moscow, Vostochnaya literatura Publ. 365 p.

Marsadolov L.S., 2016. Problemy ob'yasneniya ryada «iskazhayuschikh effektov» pri radiouglerodnom datirovanii arkheologicheskikh ob' ektov [Problems of "Deforming Effects" Explaining Using Radiocarbon Dating of Archaeological Objects]. Ecologiya drevnikh i traditsionnykh obschestv: materialy V Mezhdunar. nauch. konf. [Ecology of the Past and Traditional Societies. Proceedings of the V International Scientific Conference], iss. 5, part 2. Tumen', TSU, pp. 107-113.

Maslov V.E., 2018. K voprosu o proiskhozhdenii poyasnykh nakladok so stsenoy okhoty iz Sibirskoy kollektsii Petra I [Revisiting the Issue of Origin of Belt Mounts Featuring Hunting Scenes from the Siberian Collection of Peter I]. Kratkie soobscheniya Instituta arkheologii [BriefCommunications of the Institute of Archaeology], no. 250, pp. 25-42. DOI: http://doi.org/10.25681/IARAS.0130-2620.250.25-42.

Matveev A.V., Matveeva N.P., 1991. Savinovskiy mogil'nik sargatskoy kul'tury. Itogi polevykh issledovaniy [Savinovsky Burial Ground of the Sargat Culture. Results of Field Research]. Tumen', Institute of the Problems of Northern Developments Siberian Branch of RAS. 53 p.

Matveeva N.P., 1993a. Rafaylovskoe gorodische - pamyatnik sagatskoy kul'tury Srednego Pritobol'ya [Rafaylovsky Fortress - the Site of Sargat Culture of Middle Tobol River Basin]. Rossiyskaya arkheologiya [Russian Archaeology], no. 1, pp. 148-163.

Matveeva N.P., 19936. Sargatskaya kul'tura na Srednem Tobole [Sargat Culture at Middle Tobol River Basin]. Novosibirsk, Nauka Publ. 175 p.

Matveeva N.P., 1994. Ranniy zheleznyi vek Priishim’ya [Early Iron Age of Ishim River Basin]. Novosibirsk, Nauka Publ. 152 p. 
Matveeva N.P., 2000. Sotsial'no-ekonomicheskie struktury naseleniya Zapadnoy Sibiri v rannem zheleznom veke [Social-Economic Structures of the West Siberian Population During Early Iron Age]. Novosibirsk, Nauka Publ. 399 p.

Matveeva N.P., 2017. Radiouglerodnaya khronologiya pamyatnikov sargatskoy kul'tury (Zapadnaya Sibir') [Radiocarbon Chronology of Sites of the Sargatka Culture of Western Siberia]. Rossiyskaya arkheologiya [Russian Archaeology], no. 4, pp. 3-20.

Matveeva N.P., Berlina S.V., Rafikova T.N., 2008. Kolovskoye gorodische. Drevnosti Ingal'skoy doliny: arkheologopaleoekologicheskoe issledovanie [Kolovsky Fortress. Sites of Ingala Valley: Archaeological-Paleoecological Research]. Vol. 2. Novosibirsk, Nauka Publ. 240 p.

Matveeva N.P., Zelenkov A.S., 2018. O zapadnosibirskikh invaziyakh v Priural'e v epokhu Velikogo pereseleniya narodov [About West Siberian Invasions to the Cis-Urals During Great Folk Movement]. Vestnik Permskogo universiteta. Istoriya [Newsletter of the Perm University. History], no. 1 (40), pp. 71-86. DOI: http://doi 10.17072/2219-3111-2018-1-71-85.

Matveeva N.P., Larina N.S., Berlina S.V., Chikunova I.Yu., 2005. Kompleksnoe izuchenie usloviy zhizni drevnego naseleniya Zapadnoy Sibiri (problemy sociokul'turnoy adaptatsii v rannem zheleznom veke) [Complex Investigation of Mode of Life of the Ancient Population in Western Siberia (Problems of Socio-Cultural Adaptation During Early Iron Age)]. Novosibirsk, Siberian Branch of Russian Academy of Sciences. 228 p.

Minyaev S.S., Elikhina Yu.I., 2010. K khronologii kurganov Noin-Uly [About Chtonology of the Noin-Ula Kurgans]. Zapiski Instituta istorii material'noy kul'tury Rossiyskoy Academii Nauk [Notes of the Institute of Material Culture History of the Russian Academy of Sciences], iss. 5. Saint Petersburg, Dmitry Bulanin Publ., pp. 169-182.

Mogilnikov V.A., 1972. K voprosu o sargatskoy kul'ture [Revisiting the Issue of Sargat Culture]. Problemy arkheologii $i$ drevney istorii ugrov [Problems of the Ugrian Archaeology and Ancient History]. Moscow, Nauka Publ., pp. 66-86.

Mogilnikov V.A., 1987. Lesostepnoe Zaural'e (bakal'skaya kul'tura) [Forest-Steppe Trans-Urals (Bakal'skaya Culture)]. Finno-ugry i balty v epokhy srednevekov'ya. Arkheologiya SSSR [Fenno-Ugrians and Balts During Middle Age. Archaeology of the USSR]. Moscow, Nauka Publ., pp. 179-183.

Mogilnikov V.A., 1992a. Lesostep' Zaural'ya i Zapadnoy Sibiri [Forest-Steppe of the Trans-Urals and Western Siberia]. Stepnaya polosa Asiatskoy chasti SSSR v skifo-sarmatskoe vremya. Arkheologiya SSSR [Steppe Belt of Asiatic Part of USSR During Scythian-Sarmatian Age. Archaeology of the USSR]. Moscow, Nauka Publ., pp. 274-311.

Mogilnikov V.A., 1992b. Khunnu Zabaykal'ya [Huns of the Trans-Baikal]. Stepnaya polosa Asiatskoy chasti SSSR $v$ skifo-sarmatskoe vremya. Arkheologiya SSSR [Steppe Belt of Asiatic Part of USSR During ScythianSarmatian Age. Archaeology of the USSR]. Moscow, Nauka Publ., pp. 254-273.

Moshkova M.G., 1989a. Srednesarmatskaya kul'tura [Mid Sarmatian Culture]. Stepi evropeyskoy chasti SSSR v skifo-sarmatskoe vremya. Arkheologiya SSSR [Steppe of European Part of USSR During Scythian-Sarmatian Age. Archaeology of the USSR]. Moscow, Nauka Publ., pp. 177-191.

Moshkova M.G., 1989b. Pozdnesarmatskaya kul'tura [Late Sarmatian Culture]. Stepi evropeyskoy chasti SSSR v skifo-sarmatskoe vremya. Arkheologiya SSSR [Steppe of European Part of USSR During Scythian-Sarmatian Age. Archaeology of the USSR]. Moscow, Nauka Publ., pp. 191-202.

Moshkova M.G., Gening V.F., 1972. Abatskie kurgany i ikh mesto sredi lesostepnykh kul'tur Zaural'ya i Zapadnoy Sibiri [Abatsky Kurgans and Their Correlation with Forest-Steppe Cultures of the Trans-Urals and Western Siberia]. Pamyatniki Yuzhnogo Priural'ya i Zapadnoy Sibiri sarmatskogo vremeni [Sites of the Southern Cis-Urals and Western Siberia During Sarmatian Age]. Materialy i Issledovaniya po Arkheologii, iss. 153. Moscow, Nauka Publ., pp. 87-118.

Pilipenko A.S., Cherdantsev S.V., Trapezov R.O., Molodin V.I., Kobeleva L.S., Pozdnyakov D.V., Polosmak N.V., 2017. Paleogeneticheskoye issledovanie rodstva pogrebennykh iz kurganov sargatskoy kul'tury v Barabinskoy lesostepi (Zapadnaya Sibir') [Kinship Analysis of Human Remains from Sargat Mounds, Baraba ForestSteppe, Western Siberia]. Arkheologiya, etnographiya I antropologiya Evrazii [Archaeology, Ethnography and Anthropology of Eurasia], vol. 45, no. 4, pp. 132-142. DOI: https://doi.org/10.17746/15630102.2017.45.4.132-142.

Polosmak N.V., 1987. Baraba v epokhy rannego zheleza [Baraba During Early Iron Age]. Novosibirsk, Nauka Publ. $144 \mathrm{p}$. 
Razhev D.I., 2009. Bioantropologiya naseleniya sargatskoy obschnosti [Bioanthropology of the Population of the Sargat Entity]. Ekaterinburg, Urals Branch of RAS. 492 p.

Razhev D.I., Kovrigin A.A., 1999. Kurgannye mogil'niki sargatskoy kul'tury i sotsial'no-demographicheskaya struktura drevnego obschestva [Kurgan Cemeteries of Sargat Culture and Social-Demographic Structure of the Past Society]. Ecologiya drevnikh i srednevekovykh obschestv [Ecology of the Past and Medieval Societies. Abstracts of Papers of the Conference Devoted to 275 Anniversary of Russian Academy of Sciences]. Tumen', Institute of the Problems of Northern Developments Siberian Branch of Russian Academy of Sciences, pp. 171-175.

Rafikova T.N., 2011. Bakal'skaya kul'tura lesostepnogo i podtaezhnogo Tobolo-Ishim'ya: avtoref. dis. ... kand. ist. nauk [Bakal'skaya Culture of the Forest-Steppe and Taiga Zones of Tobol and Ishim Rivers Basin. Cand. hist. sci. abs. diss.]. Tumen'.19 p.

Salnikov K.V., 1956. Isetskie drevnie poseleniya [Ancient Settlements of Iset' River Basin]. Sovetskaya arkheologiya [Soviet Archaeology], no. 25, pp. 189-215.

Smirnov K.F., Popov S.A., 1972. Savromato-sarmatskie kurgany u s. Lipovka Orenburgskoy oblasti [SauromatianSarmatian Kurgans Nearby Lipovka Orenburg Region]. Pamyatniki Yuzhnogo Priural'ya i Zapadnoy Sibiri sarmatskogo vremeni [Sites of the Southern Cis-Urals and Western Siberia During Sarmatian Age]. Materialy i Issledovaniya po Arkheologii, iss. 153. Moscow, Nauka Publ., pp. 3-26.

Sorokin S.S., 1977. Pogrebeniya epokhi velikogo pereseleniya narodov v rajone Pazyryka [Burials of the Great Folk Movement Age in Pazyryk Area]. Arkheologicheskiy sbornik Gosudarstvennogo Ermitazha [Archaeological Volume of the State Hermitage]. Leningrad, Avrora Publ., iss. 18, pp. 57-67.

Stoyanov V.E., 1970. Klassifikatsiya i periodizatsiya zapadnosibirskikh lesostepnykh pamyatnikov rannego zheleznogo veka [Classification and Chronology of the Forest-Steppe Sites in Western Siberia During the Iron Age]. Problemy chronologii i kul'turnoj prinadlezhnosti arkheologicheskikh pamyatnikov Zapadnoj Sibiri [Problems of the Cultural and Chronological Attribution of the West Siberian Archaeological Sites]. Tomsk, Tomsk University, pp. 238-253.

Khazanov A.M., 1963. Genezis sarmatskikh bronzovykh zerkal [Genesis of the Sarmatian Bronze Mirrors]. Sovetskaya arkheologiya [Soviet Archaeology], no. 9, pp. 58-71.

Khazanov A.M., 1971. Ocherki voennogo dela sarmatov [Essey on Sarmatian Warfare]. Moscow, Nauka Publ. $172 \mathrm{p}$.

Chikunova I.Yu., 2017. Ipkul'skiy kurganny mogil'nik (resul'taty raskopok 2010-2011 gg.) [Ipkul'sky Burial Ground (Results of the 2010-2011 Excavations)]. ABORIGIN: arkheologo-etnographicheskiy sbornik [ABORIGIN: Archaeological-Ethnographic Volume], iss. 9, Tumen', Tumen' State University, pp. 79-110.

Sharapova S.V., 2000. Keramika rannego zheleznogo veka lesostepnogo Zaural'ya (opyt statisticheskogo analiza): avtoref. dis. ... kand. ist. nauk [Iron Age Trasn-Uralian Forest-Steppe Ceramics (Experience of Statistical Analysis). Cand. hist. sci. abs. diss.]. Izhevsk. 27 p.

Sharapova S.V., 2018. Bioarkheologiya naseleniya lesostepnogo Zaural'ya i Zapadnoy Sibiri (sargatskaya kul'tura) [Boarchaeology of the Forest-Steppe Trans-Uralian and West Siberian Population (Sargat Culture)]. Stratum Plus, no. 3, pp. 323-350.

Sharapova S.V., Pilipenko A.S., Razhev D.I., Trapezov R.O., Cherdantsev C.S., 2020. Dva muzhskikh pogrebeniya iz kurgana sargatskoy kul'tury: bioarkheologichesky i paleogenetichesky obzor [Two Male Burials from the Sargat Culture's Burial: Bioarchaeological and Paleogenetic Review]. Stratum Plus, no. 3, pp. 379-404.

Akhmedov I., 2007. Le harnachement de Tsibilium. A propos de la formation du type "pontique" de harnachement de l'époque des Grandes Migration. Tsibilium. La nécropole apsile de Tsibilium. Ĺ étude du site. Vol. 2. Oxford (BAR International Series S1721), pp. 67-72.

Bronk Ramsey C., 2017. OxCal 4.3. URL: http://c14.arch.ox.ac.uk (accessed 10 September 2019).

Daire M.-Y., Koryakova L., Buldashov V., Courtaud P., Epimajov A., Gonzalez E., Kovrigin A., Kosintsev P., Langouet L., Makhonina G., Marguerie D., Pautreau J.-P., Rajev D., Sharapova S., Uge M.-C., 2002. Habitats et necropolis de l'Age du Fer au Carrefour de l'Eurasie. Les fouilles de 1993 à 1997. Memoires de la mission archeologique francaise en Asie Centrale. Tome XI. Paris, Diffusion de Broccard. 291 p.

Reimer P.J., Bard E., Bayliss A., 2013. IntCal13 and Marine13 Radiocarbon Age Calibration Curves 0-50,000 Years Cal BP. Radiocarbon, no. 55 (4), pp. 1869-1887. 


\section{Information About the Author}

Svetlana V. Sharapova, Candidate of Sciences (History), Leading Researcher, Center of Archaeology of Metal Age, Institute of History and Archaeology Urals Branch of RAS, S. Kovalevskaya St, 16, 620990 Ekaterinburg, Russian Federation, svetlanasharapova01@mail.ru, https://orcid.org/0000-0001-9227-3767

\section{Информация об авторе}

Светлана Владимировна Шарапова, кандидат исторических наук, ведущий научный сотрудник центра археологии эпохи металла, Институт истории и археологии Уральского отделения РАН, ул. С. Ковалевской, 16, 620990 г. Екатеринбург, Российская Федерация, svetlanasharapova01@mail.ru, https://orcid.org/0000-0001-9227-3767 